\title{
TEMPERATURE AND PRECIPITATION CONDITIONS IN ARGENTINA ASSOCIATED WITH STRONG WESTERLY MID-LATITUTE
}

\author{
ADELIA PERLA ALESSANDRO \\ Dpto. de Ciencias de la Atmósfera y los Océanos. FCEN -Universidad de Bs. As. \\ perla@at1.fcen.uba.ar
}

Received April 2007 - Accepted October 2007

\begin{abstract}
This paper analyzes the incidence on temperature and precipitation of strong circulation from the west in the neighborhood of $45^{\circ} \mathrm{S}$. Circulation is estimated by a zonal index applied at $100^{\circ}, 70^{\circ}$ and $40^{\circ} \mathrm{W}$ at $500 \mathrm{hPa}$ and the strong circulation days by those which indices are smaller than the difference between the mean and the standard deviation of the daily indices from 1989 to 1998.

When strong circulation from the west is calculated at $100^{\circ} \mathrm{W}$, temperature anomalies over the country are positive in general and higher than $1^{\circ} \mathrm{C}$ in southern Patagonia. Precipitation frequencies are greater than normal in southern Patagonia and the WNW of the country, and smaller in the remaining areas. Temperature anomalies are positive in practically the whole of Argentina and precipitation values greater than normal are practically confined to the south of $42^{\circ} \mathrm{S}$ when the circulation from the west is more intense at $70^{\circ} \mathrm{W}$. For the same wind conditions at $40^{\circ} \mathrm{W}$, temperature anomalies are negative in Patagonia and positive in the NE and center of the country, while the greatest precipitation frequencies are found in most of the country except the western provinces.

Temperature and precipitation values obtained under the analyzed conditions can be forecast with more than $69 \%$ probability when the index on 1 or 2 previous days was negative. Keywords: precipitation, temperature, west circulation, zonal index.
\end{abstract}

RESUMO: CONDIÇÕES DA TEMPERATURA E PRECIPITAÇÃO NA ARGENTINA ASSOCIADAS COM INTENSOS VENTOS DE OESTE NAS LATITUDES MÉDIAS

Este trabalho analisa a incidência na temperatura e precipitação da forte circulação de oeste em aproximadamente $45^{\circ} \mathrm{S}$. A circulação é estimada por um índice zonal aplicado em $100^{\circ}$, $70^{\circ}$ e $40^{\circ} \mathrm{W}$ em $500 \mathrm{hPa}$ e a forte circulação diária pelas quais estes índices são menores do que a diferenta entre a média e o desvio padrão dos índices diários de 1989 a 1998. Quando a forte circulação de oeste é calculada em $100^{\circ} \mathrm{W}$, as anomalias de temperatura sobre o país são positivas em geral e maiores do que $1^{\circ} \mathrm{C}$ no sul da Patagônia. As frequências de precipitação são maiores do que o normal no sul da Patagônia e no Oeste-Noroeste do país, e menor do que as áreas restantes. As anomalias de temperatura são positivas em praticamente toda a Argentina e os valores de precipitação são maiores do que o normal e estão praticamente confinados ao sul de $42^{\circ} \mathrm{S}$ quando a circulacão de oeste é mais intensa em $70^{\circ} \mathrm{W}$.. Para as mesmas condicões de vento em $40^{\circ} \mathrm{W}$, as anomalias de temperatura são negativas na Patagônia e positivas no Nordeste e centro do país, enquanto as maiores frequências de precipitação são encontradas na maior parte do país exceto nas províncias de oeste. Os valores de temperatura e precipitação obtidos sob condicões analisadas podem ser previstos com mais de $69 \%$ de probabilidade quando o indice de 1 ou 2 dias precedentes forem negativos. Palavras chave: circulação de oeste, precipitação, temperatura, índice zonal 


\section{INTRODUCTION}

Various authors have considered circulation indices to study atmospheric behavior, which were first used by Namías and Clapp (1951). They introduced the zonal circulation index defined as the difference between hemispherically averaged pressures, one over a subtropical latitude circle and the other over a sub-polar one. In South America during the same decade, Schwerdtfeger (1951) and Prohaska (1952) worked on local and regional circulation indices. More recently, various authors have used circulation indices in the southern hemisphere, among them Kidson (1986), Berbery et al (1989), Jones et al. (1999) and Ferreira et al. (2002).

Indices are used because they simplify the interpretation of the different states of the atmosphere and limit them by a threshold value to differentiate the phenomenon under study. Among them, the zonal index is usually defined to represent atmospheric states in middle latitudes. This index is calculated at a given level like the difference in geopotential heights between two latitudes, one low, the other high, both corresponding to middle latitudes. Indices are useful and simple tools which make it possible to relate meteorological conditions with different variables such as human irritability (Alessandro, 2003 a).

Alessandro $(1998,2001)$ analyzed long waves in the southern hemisphere. To quantify their position and amplitude in South America the author introduced three different circulation indices: meridional, zonal and curvature, applied at $500 \mathrm{hPa}$ and $1000 \mathrm{hPa}$ and in the 500/1000 hPa thickness The results showed that temperature and rainfall anomaly fields could become forecast fields in the long and mid term, once hemispheric long wave forecasting methods have been established.

Alessandro (2003 b and c, $2005 \mathrm{a}$ and c) detected and described blocking action phenomena. A zonal index I to identify these phenomena was adopted at $500 \mathrm{hPa}$ applied at $100^{\circ}, 70^{\circ}$ and $40^{\circ} \mathrm{W}$. Positive I values indicate the presence of high pressure systems at high latitudes. Of the three longitudes selected, correlations between the daily indices at $70^{\circ} \mathrm{W}$ and temperatures were significantly different from zero, negative at most stations in the region between $32^{\circ} \mathrm{S}$ to $47^{\circ} \mathrm{S}$ approximately. The same features appeared in the correlations obtained with the $40^{\circ} \mathrm{W}$ indices in the subtropical north and east of the country and in a smaller region between $47^{\circ}$ and $50^{\circ} \mathrm{S}$ for those calculated at $100^{\circ} \mathrm{W}$. Precipitation in Argentina was also found to be related significantly to the blockings detected at $70^{\circ} \mathrm{W}$. Rainy day frequencies increased to the north of $45^{\circ} \mathrm{S}$ when the blockings occurred at $70^{\circ} \mathrm{W}$; they also increased in Patagonia when blockings were detected at $100^{\circ} \mathrm{W}$ and decreased to the north of the region when they were over the Atlantic. Index I was also applied to study the relation of meteorological conditions with the days on which the waters of the Rio de la Plata were higher than the critical level (Alessandro, $2005 \mathrm{~b}$ ).

Berbery et al (1989), applied a similar index to detect blockings in the South Pacific.

The results presented in the papers mentioned above contributed to improve the knowledge of atmospheric circulation and the possibility of assessing the variations in temperature and precipitation in Argentina under the circumstances mentioned.

This paper aims at expanding the latter concept by determining the cases of most intense westerly flow and their influence on both variables.

\section{DATA AND METHODOLOGY}

Data used in this paper are daily reanalysis of the 1000 and $500 \mathrm{hPa}$ geopotential fields and daily surface temperatures at 36 stations in Argentina at 12 UTC from 1989 to 1998 supplied by Argentine National Weather Service (SMN). Temperature and geopotential height anomalies were calculated with respect to the mean monthly value for this period.

Index I used in this paper to represent atmospheric states in middle latitudes is defined as:

$$
\mathrm{I}=\mathrm{U}\left(30^{\circ} \mathrm{S}\right)+\mathrm{U}\left(60^{\circ} \mathrm{S}\right)-2 \mathrm{U}\left(45^{\circ} \mathrm{S}\right)
$$

where $\mathrm{U}$ is the zonal wind component at $500 \mathrm{hPa}$, calculated at $30^{\circ} \mathrm{S}, 60^{\circ} \mathrm{S}$ and $45^{\circ} \mathrm{S}$ in $\mathrm{m} / \mathrm{s}$. The index is calculated for three different longitudes: the first on the Pacific, west of Chile at $100^{\circ} \mathrm{W}$ (I100), the second at $70^{\circ} \mathrm{W}$ (I70) which crosses meridionally a great part of Argentina in the south and the third on the Atlantic to the east of the country at $40^{\circ} \mathrm{W}$ (I40).

The normal mean field of the zonal wind component reaches a peak close to $45^{\circ} \mathrm{S}$ (Fig. 1) so that I is negative. When the zonal component at $45^{\circ} \mathrm{S}$ is unusually weak, I is positive; i.e.: the west component is weak or the wind blows from the east. Very negative values of the index, on the contrary, will indicate an intense circulation from the west.

The index used by Berbery is similar to index I. It is somewhat more complex since it includes additional geographic points. A sample of data was analyzed and no significant differences were found between the results of both indices.

Days with very negative indices were selected to study the influence of strong circulation from the west. Thus, a series was built with the days with indices lower than the mean (Im) minus the standard deviation of the series $(\sigma)$ for the whole 1989 to 1998 period.

To study the occurrence of strong westerly circulation at the selected longitudes, periods of consecutive days with $\mathrm{I}<\mathrm{Im}-\sigma$ preceded by periods of consecutive days with positive 
$(I>0)$ or negative indices $(I<0)$ were analyzed and counted. A matrix was then built with these sequences (columns) and the number of consecutive days with different conditions prior to the occurrence of westerly circulation (rows ).

Temperature is studied using its anomalies and precipitation is analyzed by calculating relation $r$, where $r$ is the ratio between the relative frequency of rainy days in the sample taken under intense westerly circulation and the relative frequency of rainy days under all wind conditions in the period 1989-1998. This is calculated for the 3 longitudes and at the 36 meteorological stations used here (Fig.3 a).

To determine if the mean value of the sample composed of temperature anomalies under intense westerly circulation are significantly different from those under other conditions, the Student's test, the mean and the variance of both samples were calculated at each station

Statistic $t$ is defined as:

$$
\mathrm{t}=(\mathrm{Xn}-\mathrm{Xp}) / \mathrm{S}(1 / \mathrm{Nn}+1 / \mathrm{Np}) 1 / 2
$$

Where:

$$
\mathrm{S}=(\mathrm{Nn} \mathrm{Sn} 2+\mathrm{Np} \mathrm{Sp} 2 / \mathrm{Nn} 2+\mathrm{Np} 2)
$$

$\mathrm{Xn}$ : mean temperature anomalies of days with $\mathrm{I}<\mathrm{Im}$ $-\sigma$ and $\mathrm{Xp}$ : mean temperature anomalies for the remaining days of the 89-98 series.

Nn: number of days with $\mathrm{I}<\mathrm{Im}-\sigma$ and $\mathrm{Np}$ : number of remaining days

S: Total Variance, Sn: Variance of days with $(\mathrm{Im}-\sigma), \mathrm{Sp}$ : Variance of the remaining days.

The Student's t test was also applied to analyze the behavior of rainfall under conditions of strong westerly circulation. To do so, two samples were studied, one with the rain days under strong westerly flow and the other containing the rain days remaining in the series 89-98.

In this case:

Xn: Mean I of the days with $\mathrm{I}<\mathrm{Im}$-s on which it rained

Xp: Mean I of the days for the remaining days of the 89-98 series.
Nn: number of days with rain in the $\mathrm{I}<\mathrm{Im}$ - $\mathrm{s}$ series, and $\mathrm{Np}$ number of remaining rain days

To explain the temperature anomaly values and the rainfall relations calculated and to know the prevailing synoptic situation, the mean geopotential fields at $1000 \mathrm{hPa}$ and $500 \mathrm{hPa}$ are determined.

For the same reason and to know the deviations from normal circulation and assess the intensity of the systems, the mean anomaly fields were also calculated at those levels. They were obtained by deducting from each case under consideration the normal value (1961-1990) of the corresponding month, thus removing seasonality.

In order to determine the influence of the selected cases on both variables in the different seasons of the year, the mean geopotential height fields, their anomalies, the temperature anomalies and rainfall relations were calculated for the same levels in the seasons with more and less cases of strong intensity (summer and winter).

The most persistent cases at each of the three longitudes were examined and averaged to determine if they were different from the temperature values and rainfall relations calculated for all the days of the series. To this end, the sequences with at least three consecutive days with an index smaller than Im - $\sigma$ were considered.

\section{RESULTS}

\subsection{Statistics}

\subsubsection{Values of the thresholds used and seasonal frequencies in the Im- $\sigma$ series}

Table 1 shows first the mean values of daily indices I $(\mathrm{Im})$ and the standard deviations $(\sigma)$ of the series calculated for the whole of the 89-98 period at each of the longitudes. Values of I40 are more negative than those of I70 and I100; standard deviations however are similar. This indicates the passage of depressions or troughs in this region is more probable, which agrees with the smaller probability (Alessandro, 2003 a) of blocking anticyclones forming at the other two longitudes.

Table 1: Mean I (Im), standard deviations (s) and Im-s values. Annual (Ft) and seasonal frequencies of the period 89-98, at $100^{\circ}, 70^{\circ}$ and $40^{\circ} \mathrm{W}$.

\begin{tabular}{|l|c|c|c|c|c|c|c|c|c|c|c|c|c|c|c|}
\hline & \multicolumn{3}{|c|}{ I100 } & \multicolumn{4}{c|}{ I70 } & \multicolumn{4}{c|}{ I40 } \\
\hline Im/ & \multicolumn{3}{|c|}{$-5,68 / 32,16$} & \multicolumn{4}{c|}{$-5,24 / 28,31$} & \multicolumn{4}{c|}{$-13,81 / 32,75$} \\
\hline Im- $\sigma$ & \multicolumn{3}{|c|}{$-37,84$} & \multicolumn{3}{c|}{$-33,55$} & \multicolumn{5}{c|}{$-46,56$} \\
\hline Season & Sum. & Aut. & Win. & Spr. & Ft & Sum. & Aut. & Win. & Spr. & Ft & Sum. & Aut. & Win. & Spr. & Ft \\
\hline Frequencies & 139 & 115 & 79 & 132 & 465 & 127 & 113 & 72 & 125 & 437 & 123 & 96 & 89 & 114 & 422 \\
\hline
\end{tabular}


The third row of the table shows the differences between the Im and $\sigma$ of the series, which are the limits used to select the days in the three series analyzed.

Annual (Ft) and seasonal frequencies of days with $\mathrm{I}<\mathrm{Im}-\sigma$ are also shown. At the three longitudes, frequency is higher in summer (December, January and February) and spring (September, October and November), smaller in autumn (February, March and April) and minimum in winter (May, June and July).

\subsubsection{Ocurrence of the Im- $\sigma$ series}

Table 2 shows all the sequences of consecutive day with $\mathrm{I}<\mathrm{Im}-\sigma$ preceded by days with $\mathrm{I}<0$ or $\mathrm{I}>0$. The highest frequencies are in bold. It can be seen that 1 or 2 consecutive $\mathrm{I}<\mathrm{Im}-\sigma$ values occur more frequently after 1 or 2 days with a negative index. When the indices on previous days are positive, the frequency of days with $\mathrm{I}<\mathrm{Im}-\sigma$ is smaller.

The percentage of cases in which one or more days with positive I precede the selected days is only 11 , 14 and 10.7 for I100, I70 and I40 respectively. Those preceded by 1 or 2 days with negative I correspond to 69 ,
71 and $79 \%$ at the same longitudes. There are few cases persisting 5 or more consecutive days with indices $<\mathrm{Im}-\sigma$.

\subsubsection{Application of the Student's t Test}

Statistic $t$ is calculated for the series of temperature anomalies and rainfall frequency.

When $t$ values of temperature anomalies or frequency of precipitation days fall beyond the $80 \%$ confidence interval, the mean of samples analyzed are significantly different from each other at that confidence level. In this case, the geographical position of each station is marked with a black circle in the fields of section 3-3 (Fig.3 and 4).

For I100 the highest values of $t$, are registered in Patagonia and to a lesser degree in the center of Argentina. When the index is taken at $70^{\circ} \mathrm{W}$, the $\mathrm{t}$ farthest from the $+/-1.28$ confidence level appeared generally in Patagonia and the center of the country. In the case of I40, significant differences were found in the NW, NE and center of the country.

As for precipitation, $t$ values at this confidence level discriminate the two samples at few stations, with exception of I70.

Table 2: Sequential frequency (consecutive days with $\mathrm{I}<\mathrm{Im}$-s preceded by days with $\mathrm{I}<0$ or $\mathrm{I}>0$ ) at 100,70 and $40^{\circ} \mathrm{W}$.

\begin{tabular}{|c|c|c|c|c|c|c|c|c|c|c|c|c|c|c|c|c|c|c|c|}
\hline \multicolumn{20}{|c|}{ Number of consecutive days with $\mathrm{I}<\mathrm{Im}-\sigma$} \\
\hline \multirow{7}{*}{ 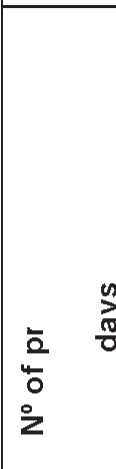 } & & 1 & 2 & 3 & 4 & 5 & $? 6$ & 1 & 2 & 3 & 4 & 5 & $? 6$ & 1 & 2 & 3 & 4 & 5 & $? 6$ \\
\hline & 1 & 5 & 2 & & & & & 10 & 1 & 5 & 1 & & & 10 & 2 & 2 & & & \\
\hline & 2 & 1 & 3 & & 1 & & & 4 & 1 & 1 & & & & 3 & 1 & & & & \\
\hline & 3 & 2 & 2 & & & & & 1 & 1 & & & & & 1 & & & & & \\
\hline & 4 & 3 & & 1 & & & & 1 & & 1 & & & & 2 & & 1 & & & \\
\hline & 5 & & 2 & & & & 1 & 3 & & & & 1 & & & & & & & \\
\hline & $? 6$ & 1 & 1 & & & & & & & 1 & 1 & 1 & & 2 & 2 & & & & \\
\hline \multirow{7}{*}{ 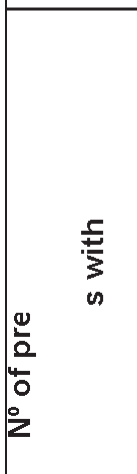 } & 1 & 48 & 26 & 14 & 5 & & 3 & 45 & 25 & 8 & 3 & & & 45 & 26 & 4 & 4 & & 1 \\
\hline & 2 & 18 & 12 & 7 & 2 & & 2 & 25 & 13 & 8 & & 1 & 1 & 33 & 10 & & & & 1 \\
\hline & 3 & 14 & 10 & 1 & 1 & 2 & 2 & 19 & 7 & 1 & 2 & 1 & & 18 & 11 & 5 & 1 & 1 & \\
\hline & 4 & 10 & 2 & 2 & & 1 & & 8 & 8 & 3 & 2 & 1 & & 14 & 3 & 3 & 2 & 1 & \\
\hline & 5 & 10 & 2 & & 1 & & & 6 & 2 & 1 & & 2 & & 8 & 4 & & & & \\
\hline & $? 6$ & 12 & 5 & 4 & & & 1 & 8 & 5 & 2 & & & & 16 & 5 & 1 & 2 & & \\
\hline & \multicolumn{7}{|c|}{ I100 } & \multicolumn{6}{|c|}{170} & \multicolumn{6}{|c|}{140} \\
\hline
\end{tabular}



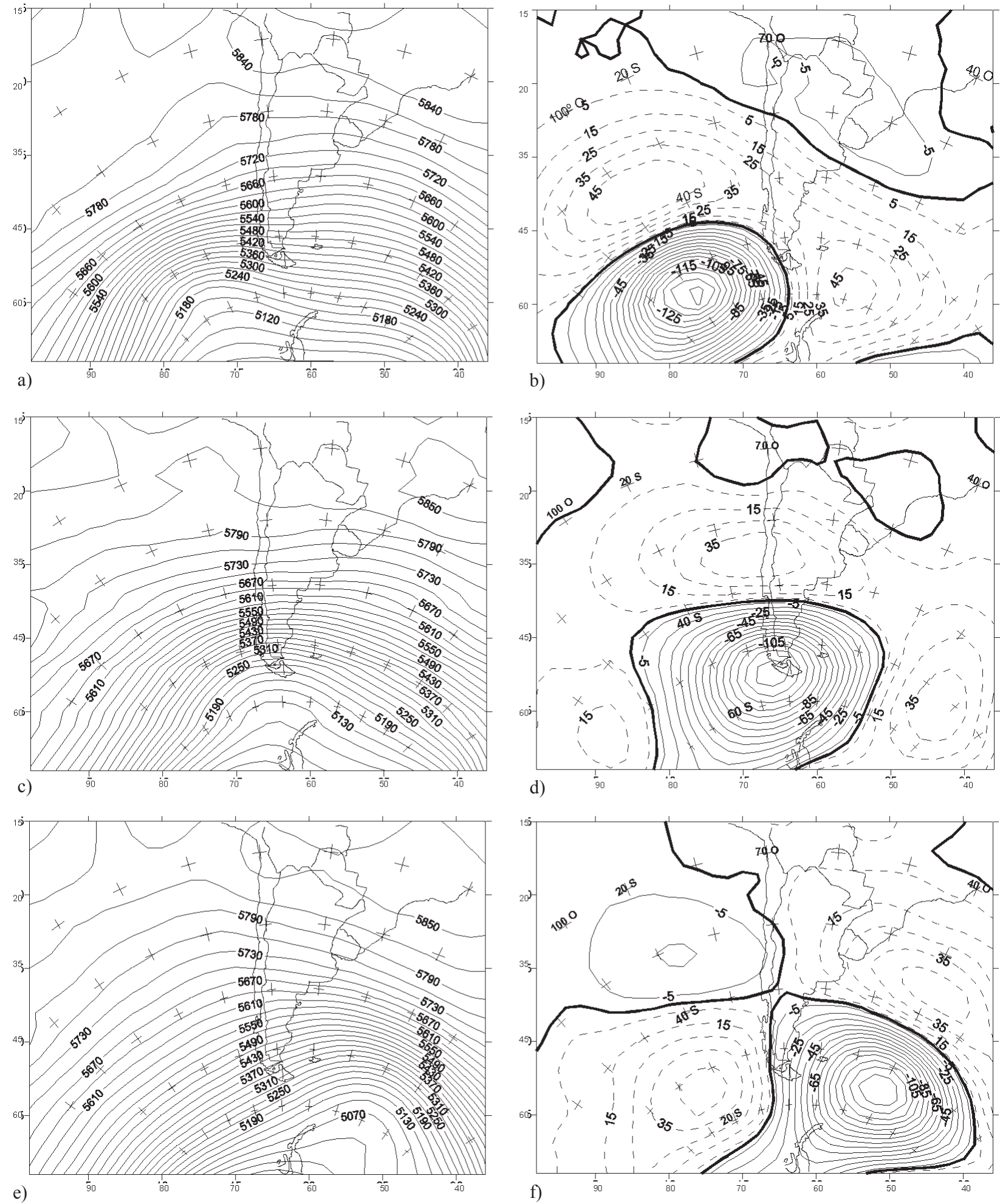

Figure 1 - Mean geopotential height fields at $500 \mathrm{hPa}\left(\mathrm{a}, \mathrm{c}\right.$ and e) and their anomalies (b, $\mathrm{d}$ and f) when I is calculated at $100^{\circ} \mathrm{W}(\mathrm{I} 100), 70^{\circ} \mathrm{W}(\mathrm{I} 70)$ and $40^{\circ} \mathrm{W}$ (I40). Dash (full) lines represent positive (negative) values. 

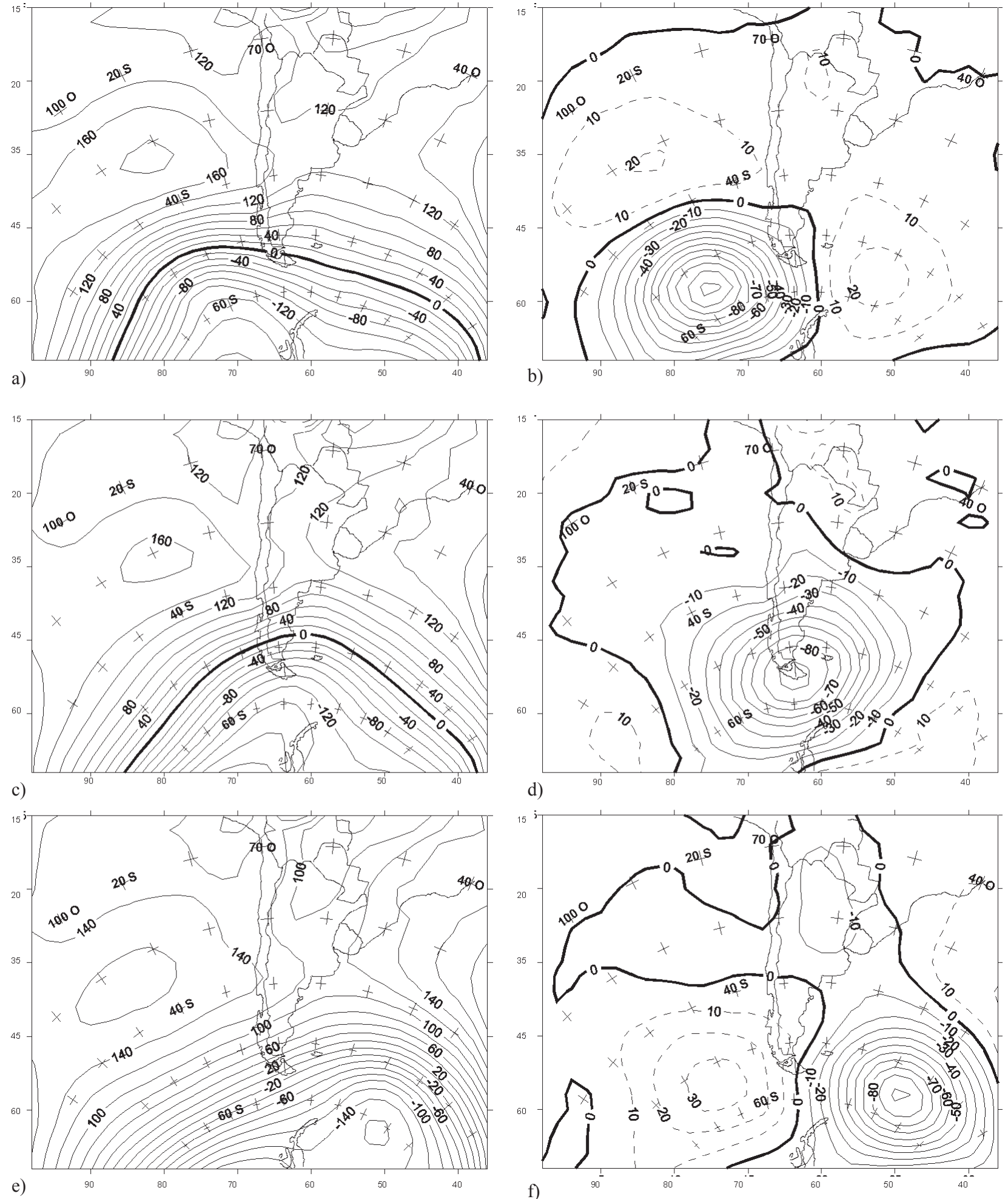

Figure 2 - Mean geopotential height fields at $1000 \mathrm{hPa}$ (a, c and e) and their anomalies (b, d and f) for I100, I70 and I40. Dash (full) lines represent positive (negative) values. 


\subsection{Mean geopotential height fields and their anomalies corresponding to the days of series Im- $\sigma$}

The mean geopotential height fields at $500 \mathrm{hPpa}$ (Fig.1 a, c and e) and $1000 \mathrm{hPa}$ (Fig.2 a, c and e) for the days with daily indices are smaller than Im- $\mathrm{s}$ are shown for each of the three longitudes. A strong gradient to the south of $40^{\circ} \mathrm{S}$, a cyclonic center located approximately at $60^{\circ} \mathrm{S}$ and over the longitudes where the indices have been calculated can be seen in all the fields, i.e., at $100^{\circ}, 70^{\circ}$ and $40^{\circ} \mathrm{W}$.

Both levels are very similar to the south of $40^{\circ} \mathrm{S}$ with the cyclonic centers practically at the same geographical position.. At I70, there is a trough over La Pampa Province and SW Buenos Aires Province and at I40 a more pronounced trough to the east of Buenos Aires. The geopotential height gradient at $1000 \mathrm{hPa}$ between Neuquén $\left(38.57^{\circ} \mathrm{S}, 68.08^{\circ} \mathrm{W}\right)$ and Ushuaia $\left(54.48^{\circ} \mathrm{S}\right.$, $68.19^{\circ} \mathrm{W}$ ) is 160,255 and $150 \mathrm{mgp}$ at I100, I70 and I40 respectively.

The mean geopotential height anomalies for all the previous fields appear in Fig. 1 b, $d$ and $\mathrm{f}$ and Fig.2 b, d and f. There is a markedly high negative value of anomalies around $55^{\circ} \mathrm{S}$, corresponding to the centers in the south mentioned above. At $1000 \mathrm{hPa}$, the region affected by intense circulation from the west is strongly marked by the zero isoline. Anomaly values at $1000 \mathrm{hPa}$ for $100^{\circ}, 70$ and $40^{\circ} \mathrm{W}$ are 160,130 and $180 \mathrm{mgp}$ respectively. At $500 \mathrm{hPa}$ anomalies are 110,90 and $100 \mathrm{mgp}$ for the same longitudes. All these are very significant according to the standard deviation values for the region (Velasco et al, 1980) At both levels, these negative anomalies are practically in the same position for the three longitudes selected. At $500 \mathrm{hPa}$, however, for I70 the positive anomaly centered approximately to the south of Mendoza Province is much more defined, making weaker the northward component of the westerly circulation at $1000 \mathrm{hPa}$.

Subtropical anticyclones at $500 \mathrm{hPa}$ are more intense at the three studied longitudes, which makes them more stable with the corresponding incidence on $1000 \mathrm{hPa}$.

\subsection{Temperature anomalies and $\mathbf{r}$ rainfall relation, related to geopotential height fields.}

\subsubsection{For the $\mathbf{I}<\mathrm{Im}-\sigma$ series:}

Figures $3 \mathrm{~b}$, c and d, and Figure 4 show the mean temperature anomaly and $\mathrm{r}$ fields for the three longitudes. It can be seen that:

When the index is calculated at $100^{\circ} \mathrm{W}$ (Fig. $3 \mathrm{~b}$ and

Fig. 4 a)

To the north of $40^{\circ} \mathrm{S}$ :

In the north of Argentina there is a surface trough less intense than usual (anomaly of $+10 \mathrm{hPa}$ at $1000 \mathrm{hPa}$ ) which causes a drop in temperature anomalies in the center of the country, yet retaining enough humidity to produce rain in the NW. Rainfall is favored by a small decrease at $500 \mathrm{hPa}$ which is reflected by a negative anomaly (Fig. $1 \mathrm{~b}$ ).

The subsidence produced by the Andes and the Pacific anticyclone induces positive temperature anomalies and shortage of rain in the center and east of the country. This anticyclone is displaced over the continent and is more intense at 500 and 1000 $\mathrm{hPa}$ according to the geopotential height anomalies.

To the south of $40^{\circ} \mathrm{S}$ :

The presence of a ridge at $1000 \mathrm{hPa}$ in western Patagonia $\left(73^{\circ} \mathrm{W}\right)$, which does not reach the extreme south produces the same features as those mentioned above.

In the extreme south of Patagonia, the anomalies increase their positive value due to the winds with a NW component which produce warmer temperatures (Fig. 2 a y b). The r values are greater than one because of the trough over the Southern Pacific at 500 and $1000 \mathrm{hPa}$ (Fig.2 a). The negative values of the geopotential height anomalies at $1000 \mathrm{hPa}$ (Fig. 2 b) and $500 \mathrm{hPa}$ (Fig.1 b) indicate its depth.

When the index is calculated at $70^{\circ} \mathrm{W}$ (Fig. $3 \mathrm{c}$ and Fig. 4 b).

To the north of $40^{\circ} \mathrm{S}$ :

Fig.3 c shows an ample zone of positive temperature anomalies in practically the whole country that decrease to the north and south from a peak value of $3.5^{\circ} \mathrm{C}$ in the south of the province of Buenos Aires. The subsidence caused by the Andes and the Pacific anticyclone has an incidence on the positive anomaly values and the $\mathrm{r}$ smaller than one up to practically $35^{\circ}$ S (Fig. $1 \mathrm{c}$ and d, Fig. $2 \mathrm{c}$ and d). On the other hand, Fig. $2 \mathrm{~d}$ shows NE flow from the Atlantic anticyclone which produces an increase in temperature which reaches the center of the country. These cause a peak temperature anomaly in Bahia Blanca, where a trough at $1000 \mathrm{hPa}$ located to the east of Patagonia causes rainfall in this city.

The effect of the humidity input from the NE is annulled by an increase in $500 \mathrm{hPa}$ geopotential heights, consequence of a positive anomaly extending between 25 and $40^{\circ} \mathrm{S}$ (Fig. 1 d) at this level. This positive center is linked to the ridge close to $70^{\circ} \mathrm{W}$ which causes the drought to the north of Bariloche $\left(41.15^{\circ} \mathrm{S}, 71.17^{\circ} \mathrm{W}\right)$.

To the south of $40^{\circ} \mathrm{S}$ :

The trough at $500 \mathrm{hPa}$ over southern Argentina causes $r$ values to be greater than 1, except in NE of Patagonia (Fig. $1 \mathrm{c}$ ), and the flow from the $\mathrm{SW}$ at $1000 \mathrm{hPa}$ drives negative temperature anomalies. An extensive anomaly over Tierra del Fuego shows its intensity (Fig. 1 d).

When the index is calculated at $40^{\circ} \mathrm{W}$ (Fig. $3 \mathrm{~d}$ and Fig. 4 c).

To the north of $40^{\circ} \mathrm{S}$ :

The $1000 \mathrm{hPa}$ field has a trough to the north of 
Argentina shown by the negative height anomaly values in this zone (Fig. 2 f). This circulation causes positive temperature anomalies in the north, center and east of the country. The trough may be associated to the one appearing in eastern province of Buenos Aires and to the low pressure system in the South Atlantic, which may represent the passage of fronts. The NE flow in the NE of Argentina provides enough humidity for a general rise in $\mathrm{r}$, except in the extreme $\mathrm{W}$ where humidity advection is blocked by the Pacific anticyclone.

To the south of $40^{\circ} \mathrm{S}$ :

In this area average flow is from the $\mathrm{SW}$, which involves cases of winds with a $\mathrm{S}$ or SE component (Fig. 2 f) which transport humidity from the Atlantic to Patagonia.

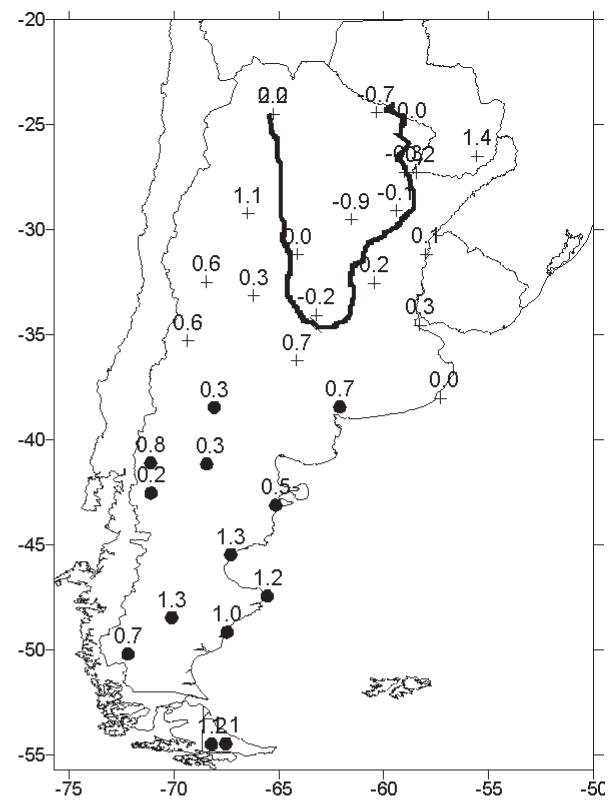

b)

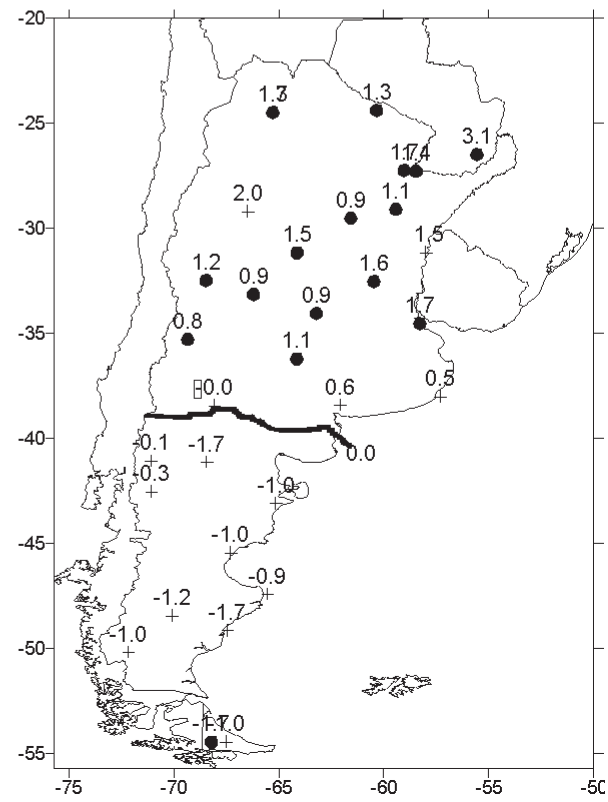

d)

Figure 3 - a). Stations used. Mean temperature anomalies when I is calculated at b) $100^{\circ} \mathrm{W}$, c) $70^{\circ} \mathrm{W}$ and d) $40^{\circ} \mathrm{W} \cdot{ }^{\bullet}$ Stations where mean temperature anomalies during episodes of strong westerly flow are significantly different from those corresponding to the rest of the series. 


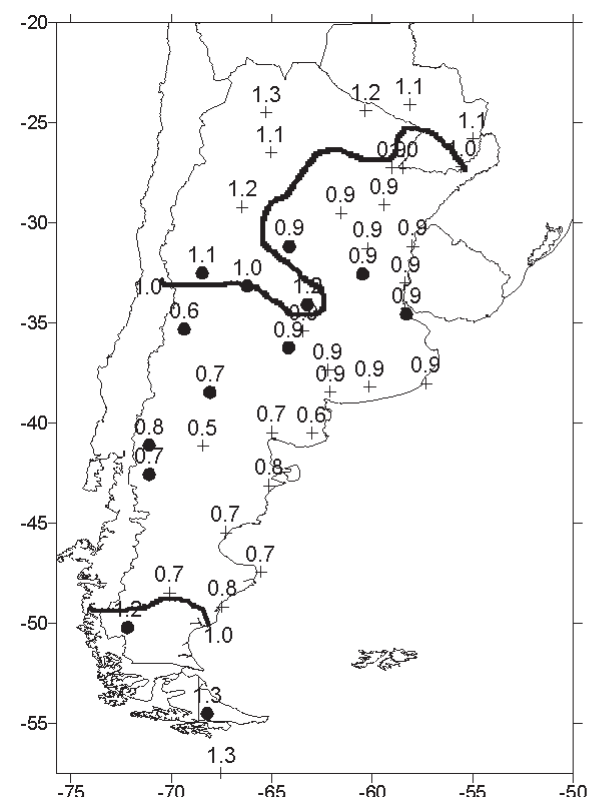

a)

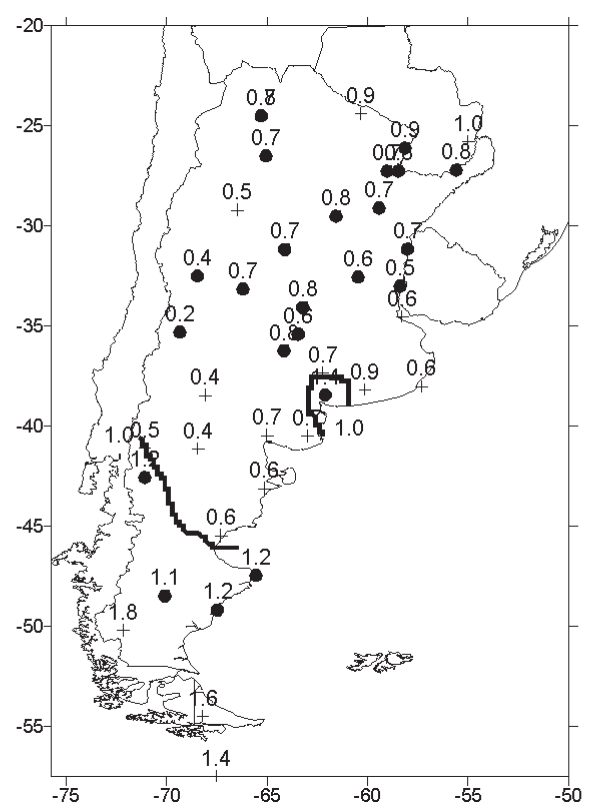

b)

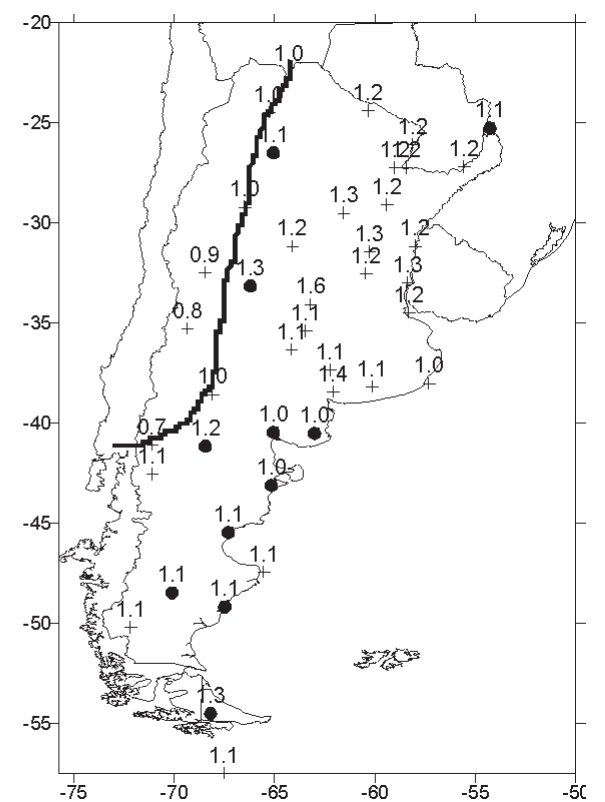

c)

Figure 4 - Mean r fields when a) I100, b) I70 and c) I40. Idem figure 3, but for precipitation frequency.

\subsubsection{In summer and winter}

Considering the mean fields, the 500 and $1000 \mathrm{hPa}$ geopotential anomalies in summer and winter (Figs.5, 6 and 7), the temperature anomalies (Fig. 8) and r (Fig. .9), it can be seen that when the index is calculated at $100^{\circ} \mathrm{W}$. (Figs. 8 and 9 , a and b):

To the north of $40^{\circ} \mathrm{S}$ :

The 500 and $1000 \mathrm{hPa}$ anomaly fields (Fig. 6 and 7, a and b) show that in winter the negative anomaly over the South Pacific is displaced to the northeast with respect to its position in summer, thus dividing a large positive anomaly expanding diagonally from the NW - SE into two positive anomaly areas, one over the Atlantic and the other over the Pacific. A trough in the $1000 \mathrm{hPa}$ mean field is associated to the negative anomaly (Fig. $5 \mathrm{a}$ and b), which passes over Bahía Blanca $\left(38.44^{\circ} \mathrm{S}\right.$, $62.1^{\circ} \mathrm{W}$ )and expands to the north. This together with a flow from the $\mathrm{NE}$ at $1000 \mathrm{hPa}$ and a negative anomaly at $500 \mathrm{hPa}$ explain rainfall occurred in winter to the north of $40^{\circ} \mathrm{S}$. Humidity does not reach the west, where $\mathrm{r}$ values are smaller than 1 .

In summer, the greater $r$ values in the NW of the country are related to the weakening of the NW depression. The Atlantic anticyclone is located farther from the continent (Fig. 5 a) and in agreement with the normal intensity anomaly values. This explains the scarce rainfall in the east of the country. The Pacific anticyclone is more intense in winter at 500 and $1000 \mathrm{hPa}$.

Wind from the south (Fig. 5 a and b), also observed in the anomaly fields, determines an area of negative temperature anomalies during both seasons. In summer it stretches over the east of the country and in winter over the north, as the influence of the wind is effective north of $20^{\circ} \mathrm{S}$. To the south of $40^{\circ} \mathrm{S}$ :

Winds from the west and the NW enter the country dry and warm during both seasons. In the extreme south of Patagonia, however, rainfall is greater than 1 as a consequence of the trough located over the southern Pacific.

When the index is calculated at $70^{\circ} \mathrm{W}$. (Figs. 8 and 9 c and d).

To the north of $40^{\circ} \mathrm{S}$ :

The two rainfall fields are very similar (Fig. $8 \mathrm{c}$ and d). In summer, the trough at $1000 \mathrm{hPa}$, located to the west of Bahía Blanca (Fig. $5 \mathrm{c}$ ) is much more pronounced than in winter and can be associated with the NW depression. Rainfall in provinces of Corrientes and Misiones and the south of Buenos Aires Province is of this origin. Rainfall in the rest of the country to the north of $40^{\circ} \mathrm{S}$ is scarce because of the influence of a positive anomaly at $500 \mathrm{hPa}$ and in the NW because of the intensification of the NW depression (Lichtenstein, 1980).

In winter, the Atlantic anticyclone is strongly displaced to the west (Fig. 5 d) as can be seen in the mean field of 1000 $\mathrm{hPa}$ and in the anomalies, which means less rainfall than in summer. This field shows a southerly wind component in the northernmost area of the country that causes negative temperatures.

To the south of $40^{\circ} \mathrm{S}$ :

It rains over a more ample area in winter, as a trough is located over the center of Patagonia. In summer, the trough is over Bahia Blanca (Fig. 5 a). 


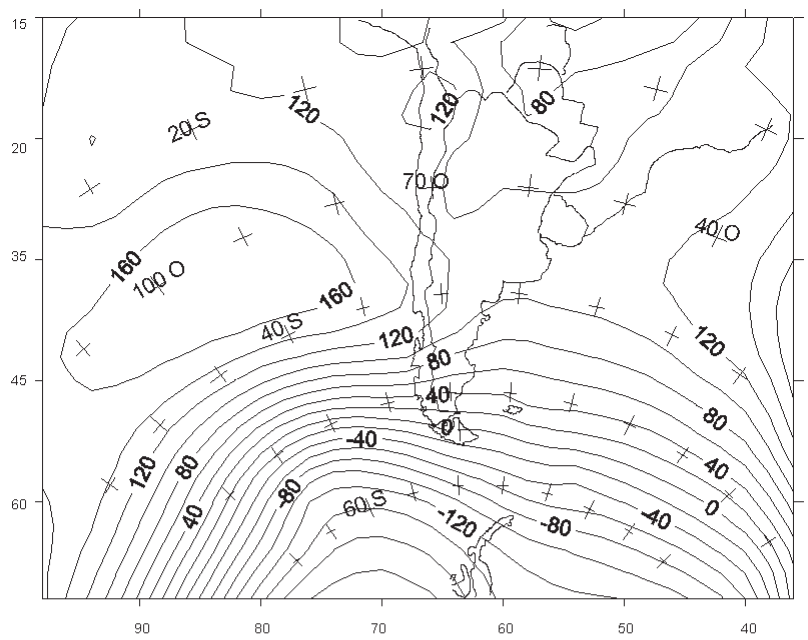

a) Summer

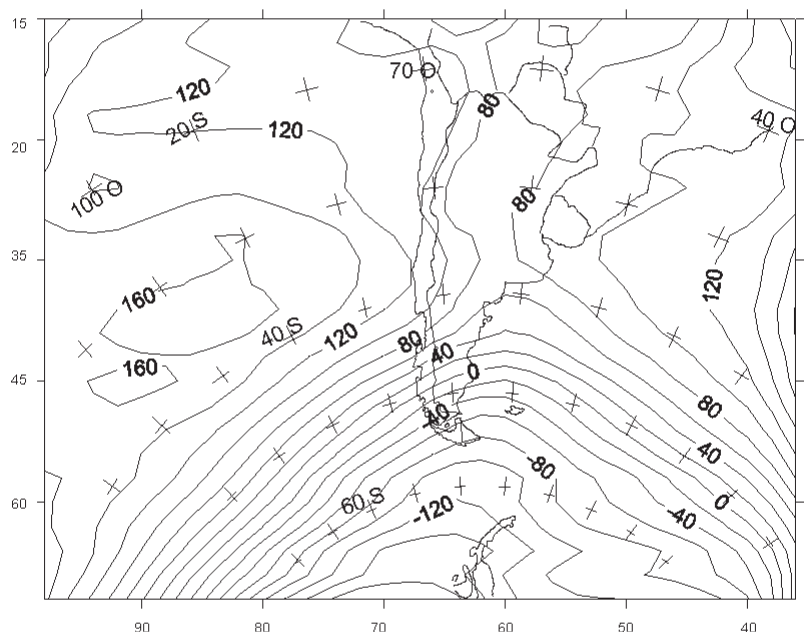

c) Summer

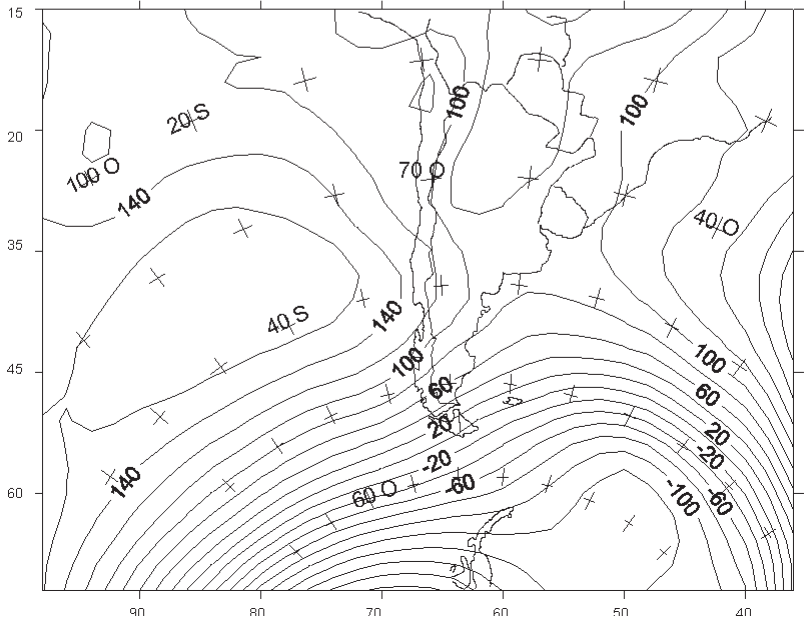

e) Summer

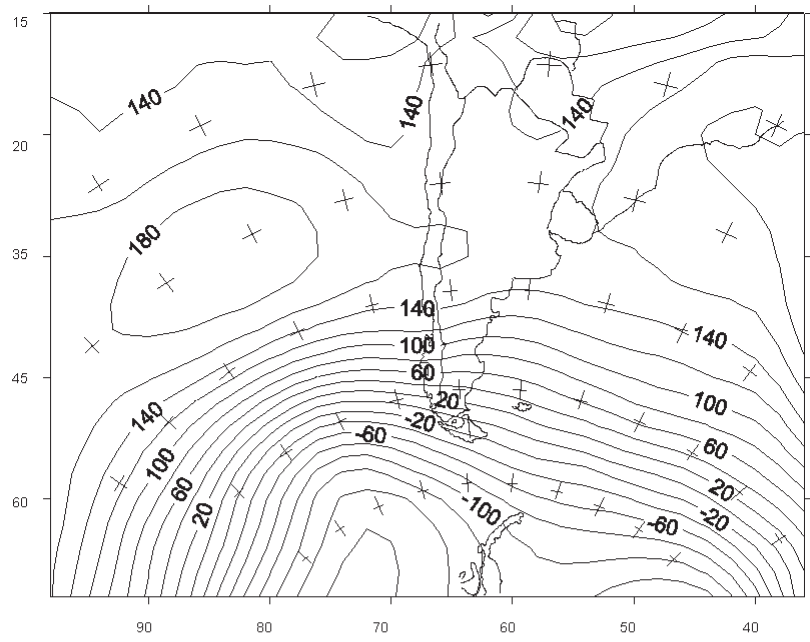

b) Winter
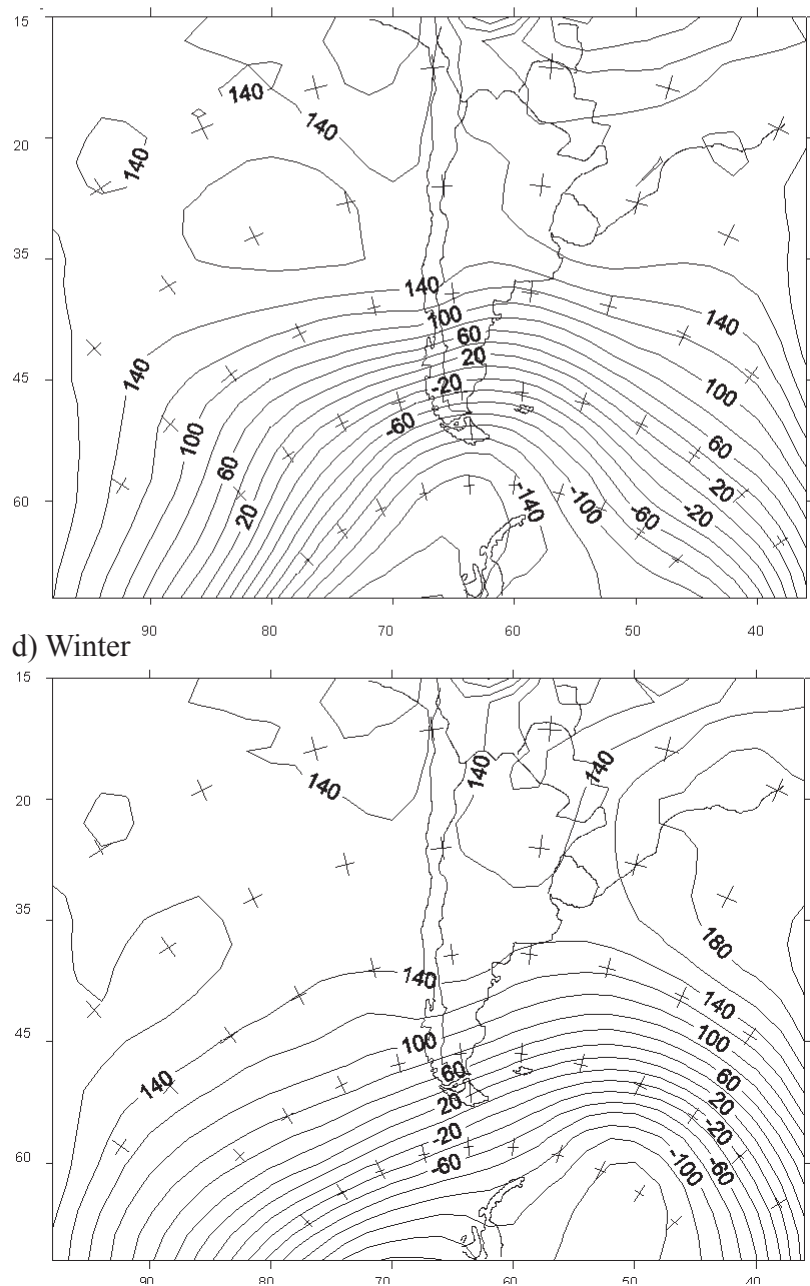

f) Winter

Figure 5 - Mean geopotential height fields in summer and winter at $1000 \mathrm{hPa}$ for I100, I70 and I40. 

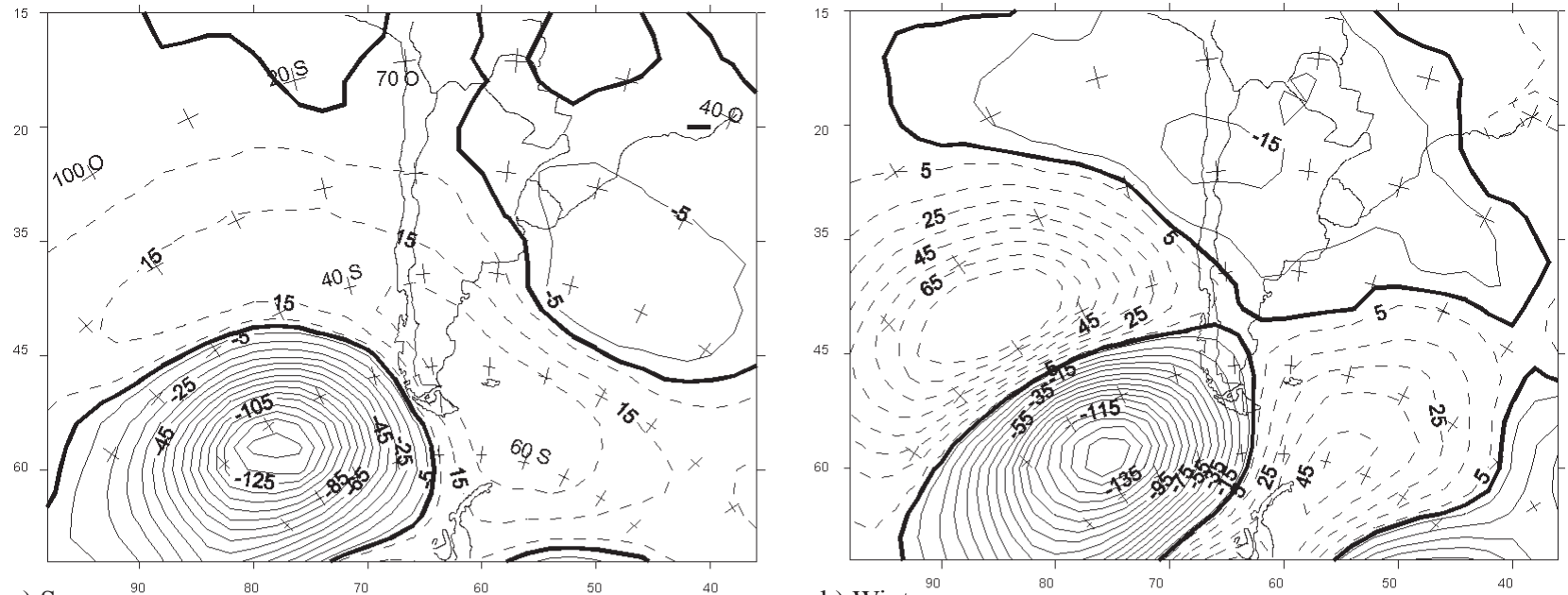

a) Summer

b) Winter

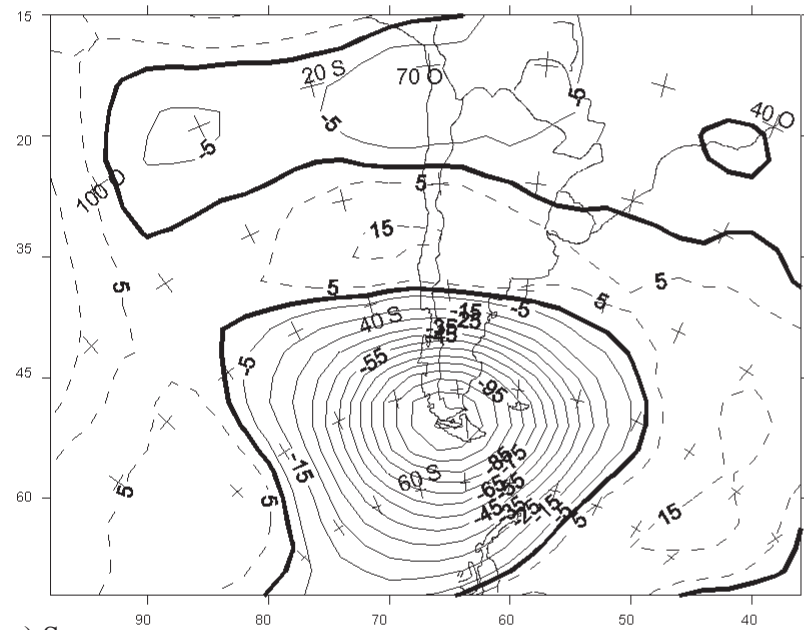

c) Summer
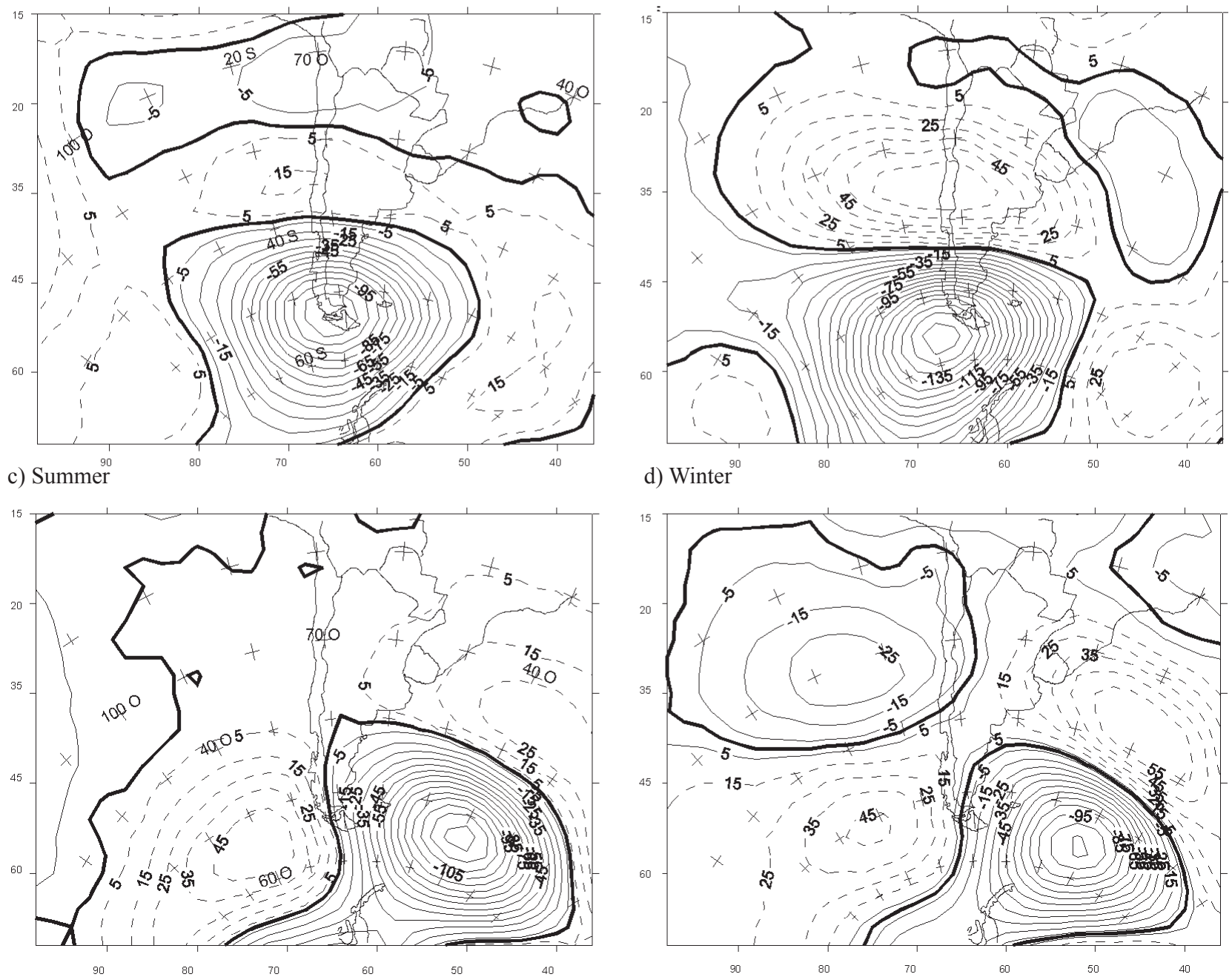

e) Summer

d) Winter

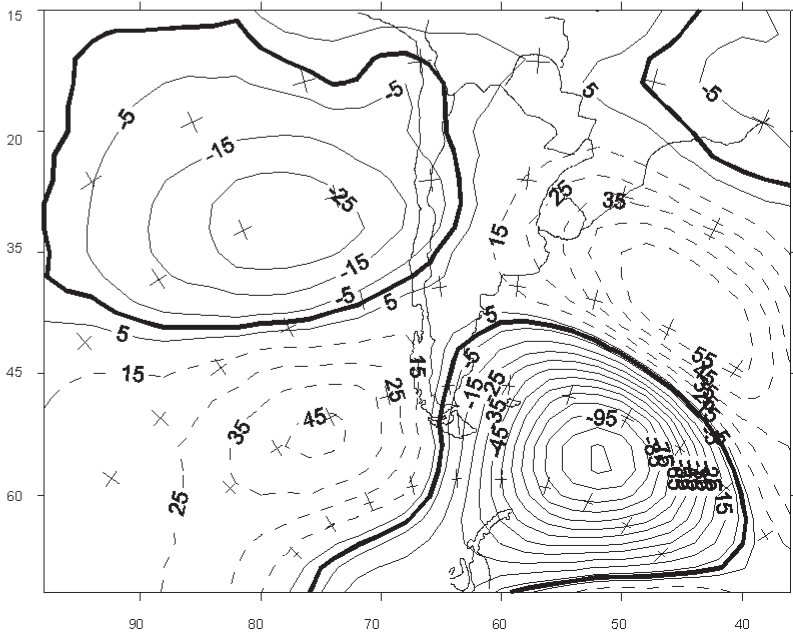

f) Winter

Figure 6 - Mean geopotential height anomalies in summer and in winter at $500 \mathrm{hPa}$ for I100, I70 and I40. 


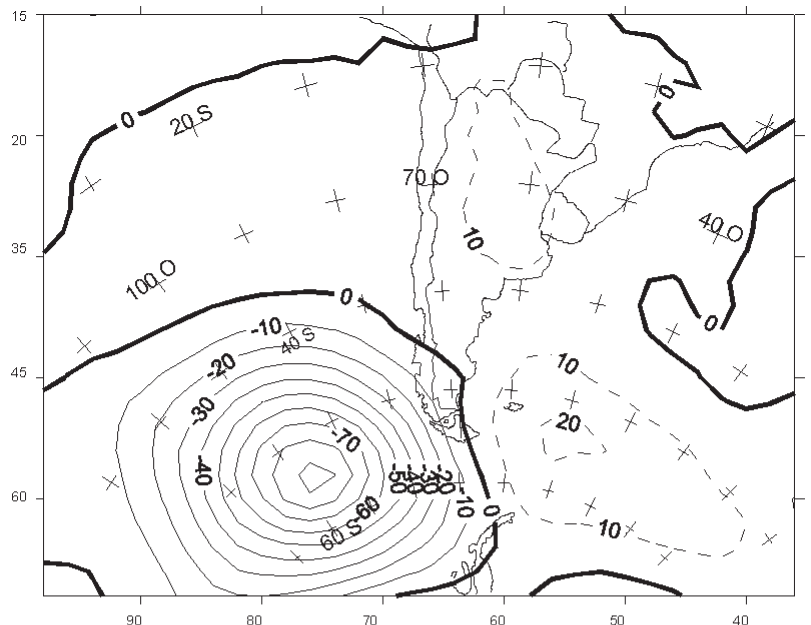

a) Summer

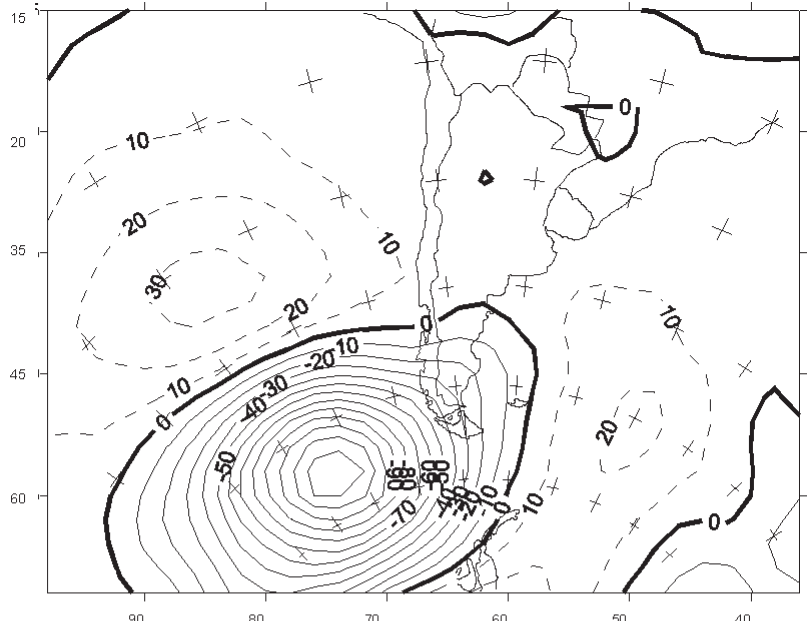

b) Winter
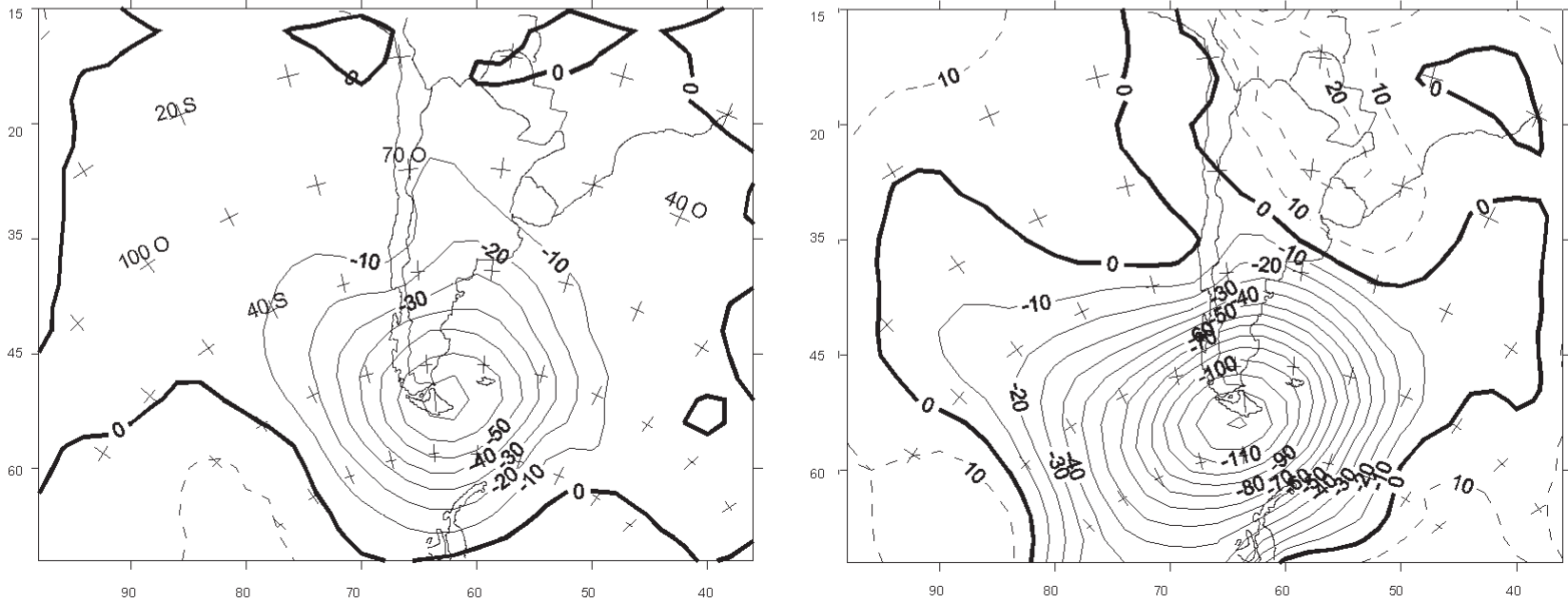

c) Summer

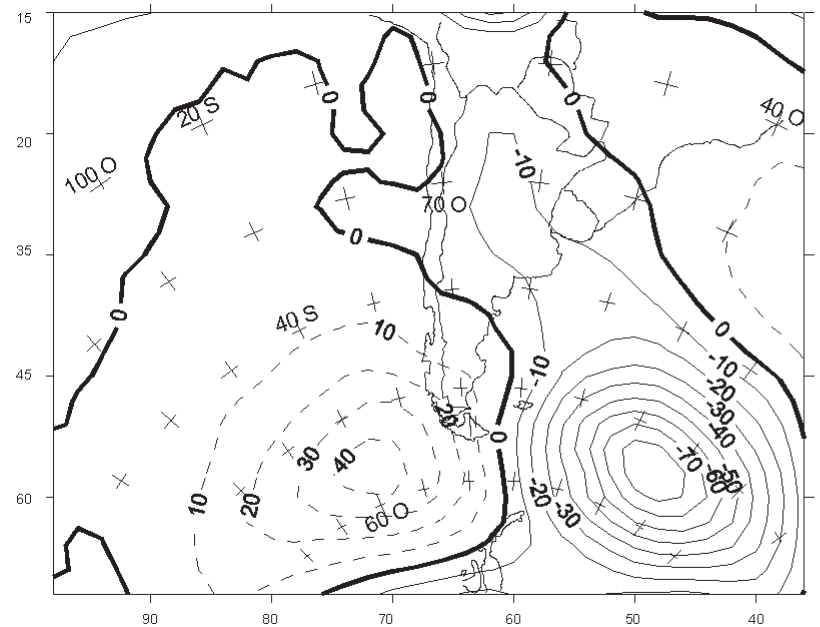

d) Winter

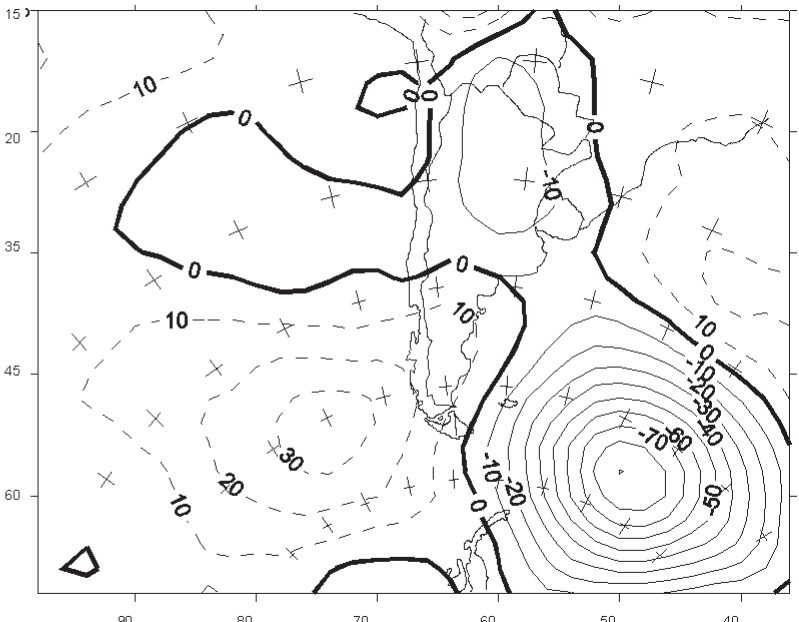

e) Summer

f) Winter

Figure 7 - Mean geopotential height anomalies in summer and winter at $1000 \mathrm{hPa}$ for I100, I70 and I40. 

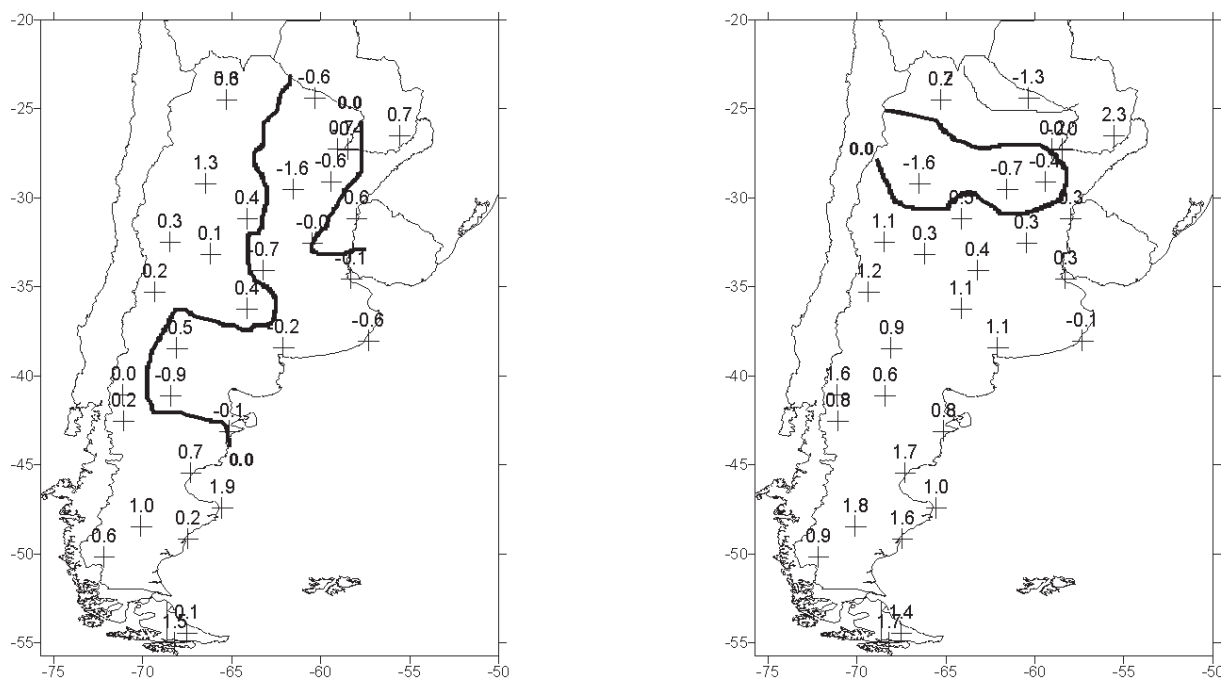

a) Summer

c) Summer
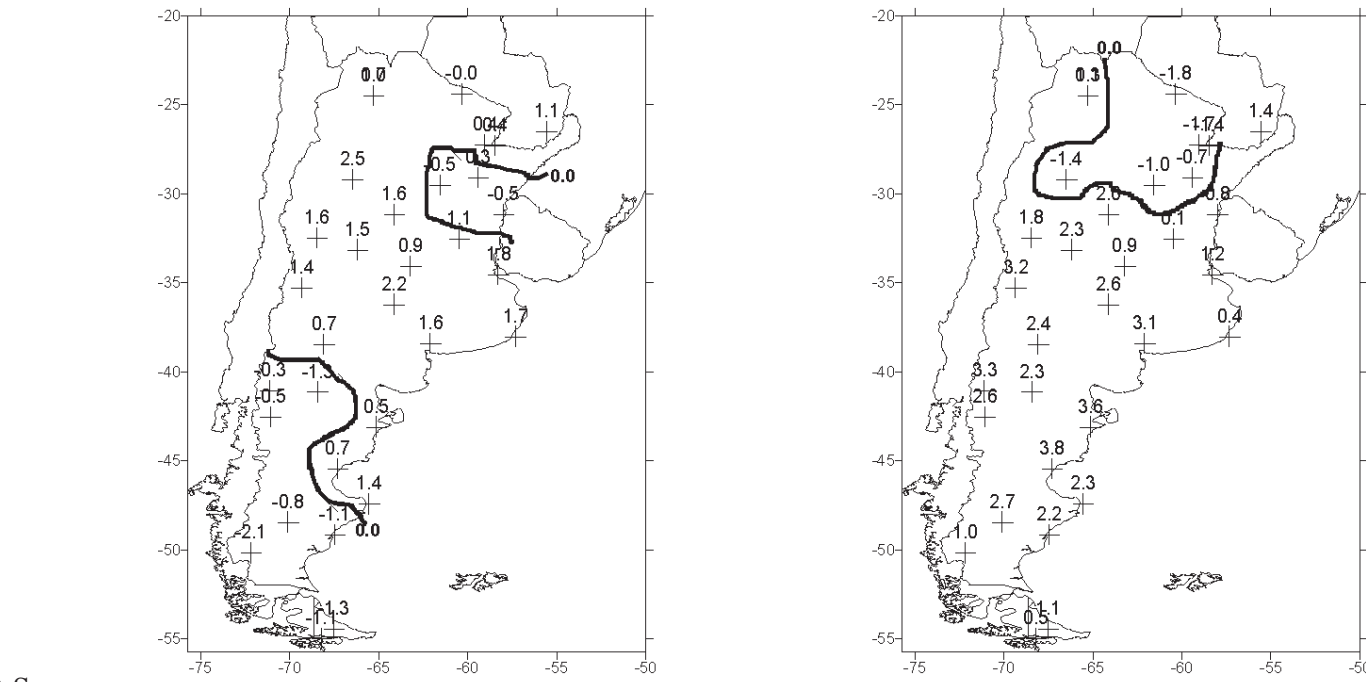

b) Winter

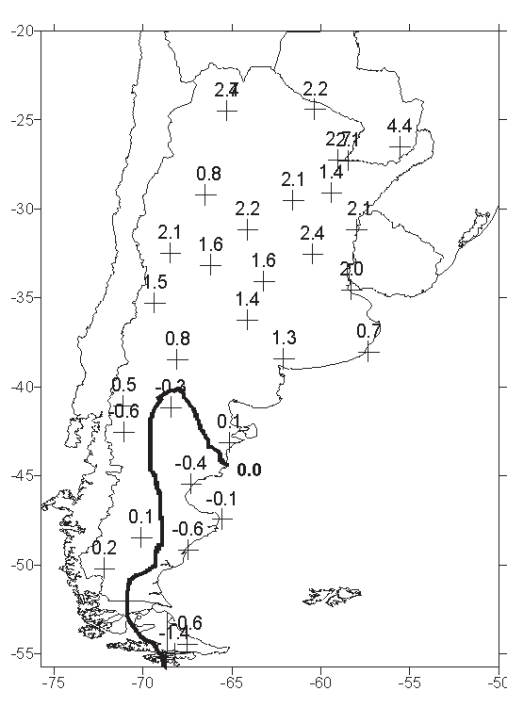

d) Winter

e) Summer

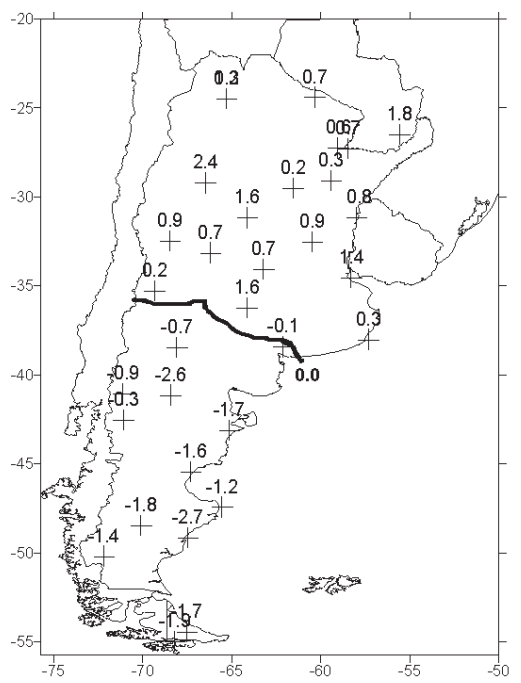

f) Winter

Figure 8 - Mean temperature anomaly fields in summer and winter for I100, I70 and I40. 
a) Summer

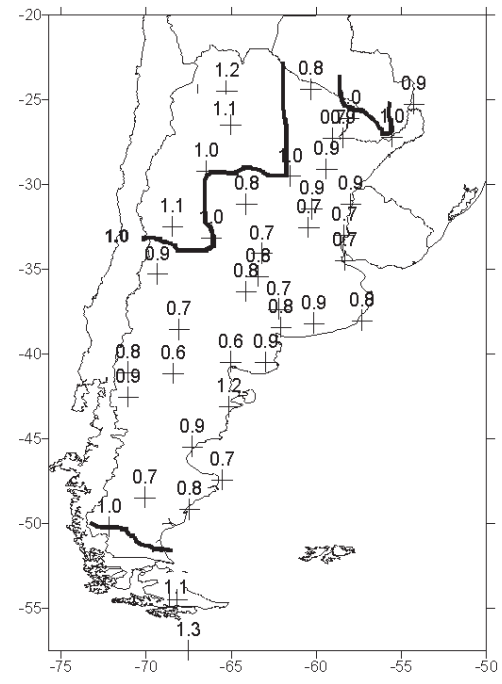

c) Summer
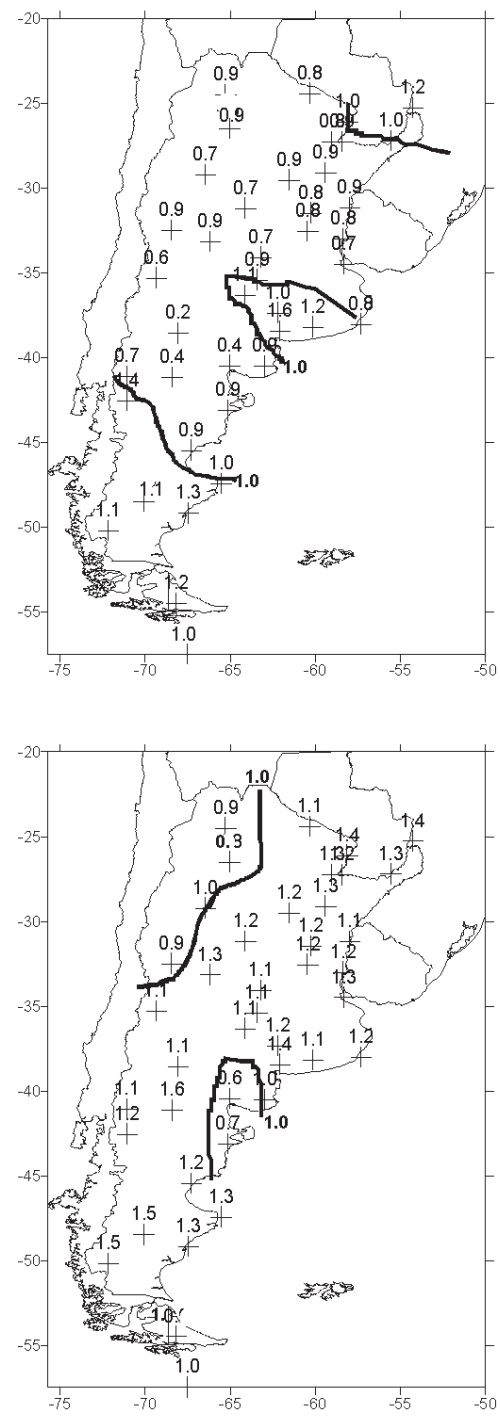

e) Summer

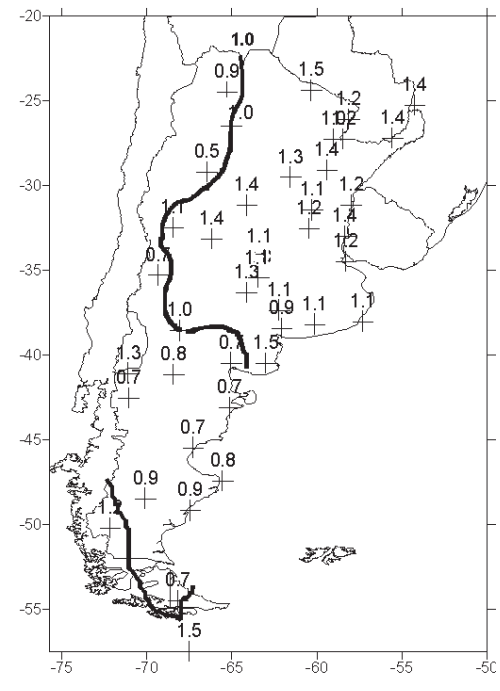

b) Winter

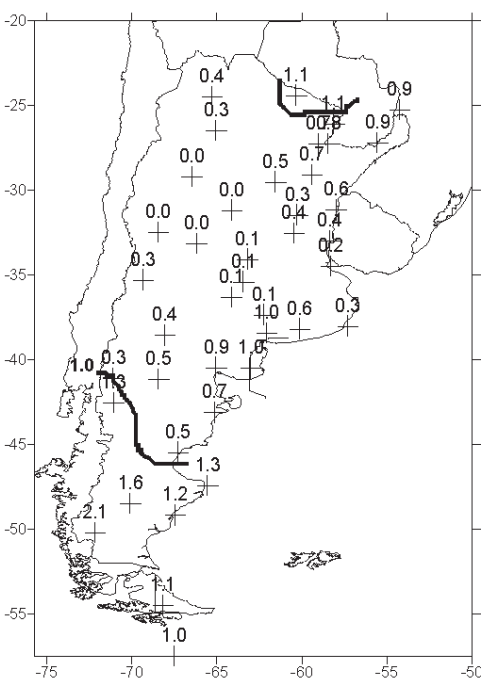

d) Winter

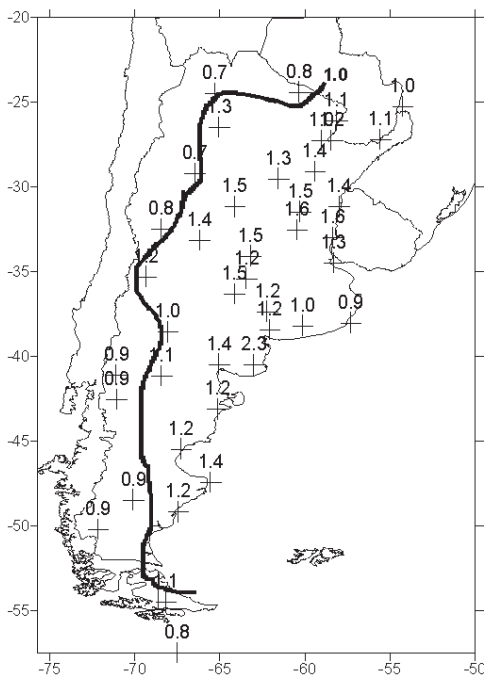

f) Winter

Figura 9 - $r$ fields in summer and winter when I100, I70 and I40. 

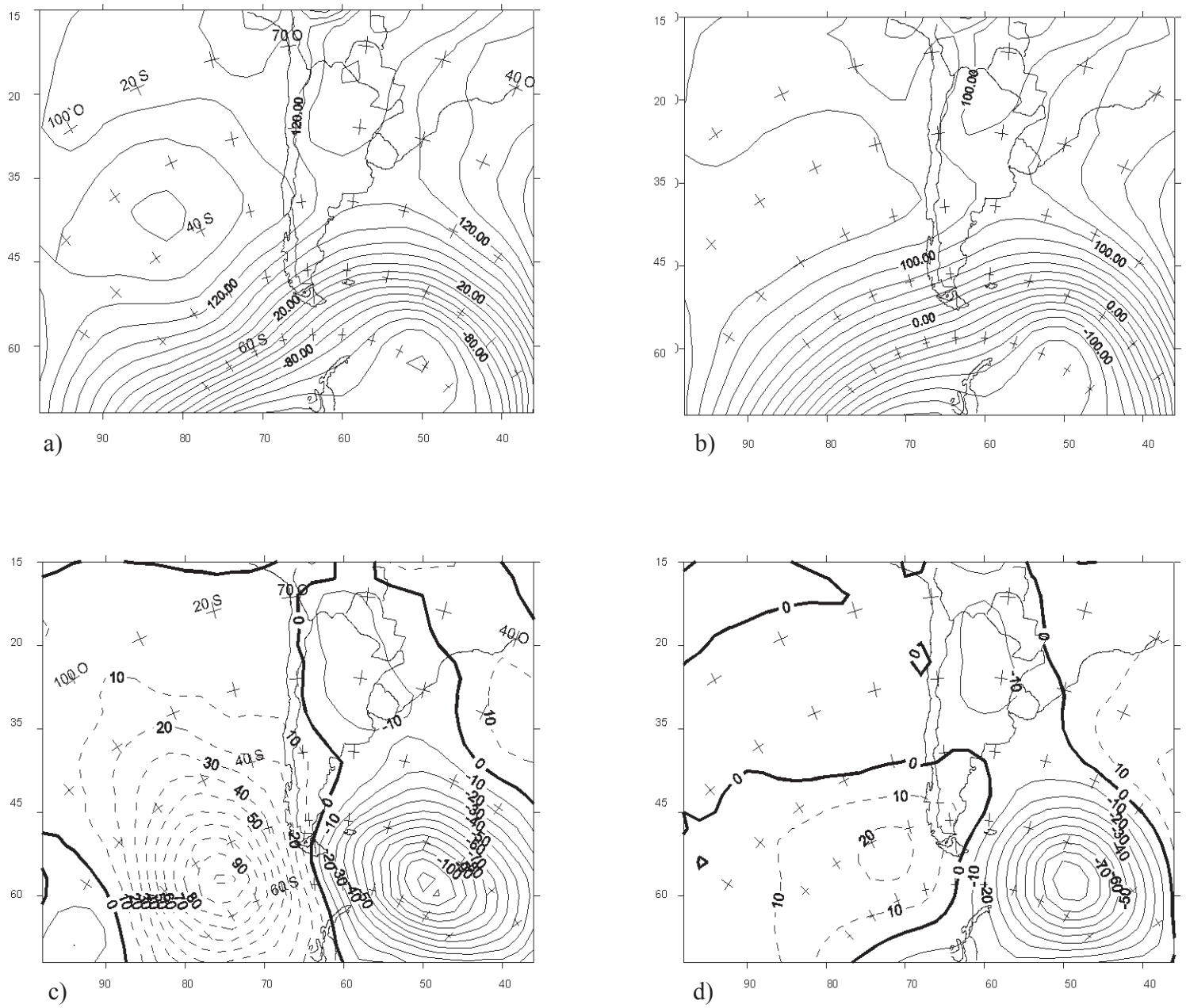

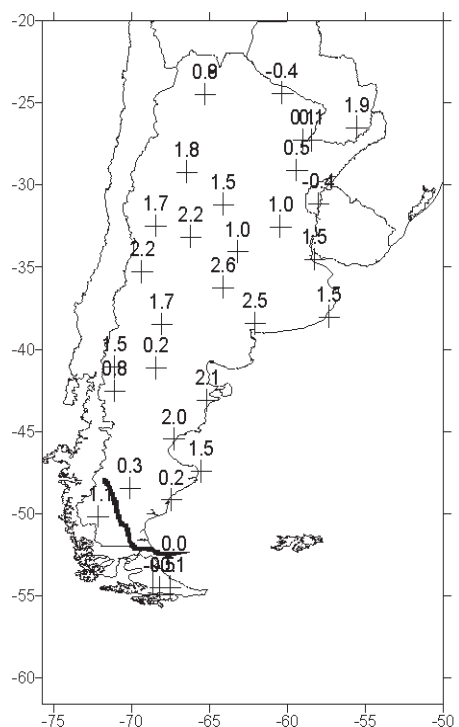

e)

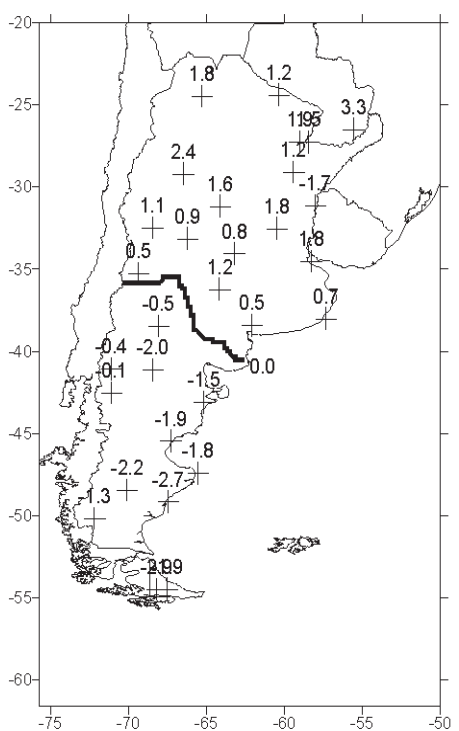

f)

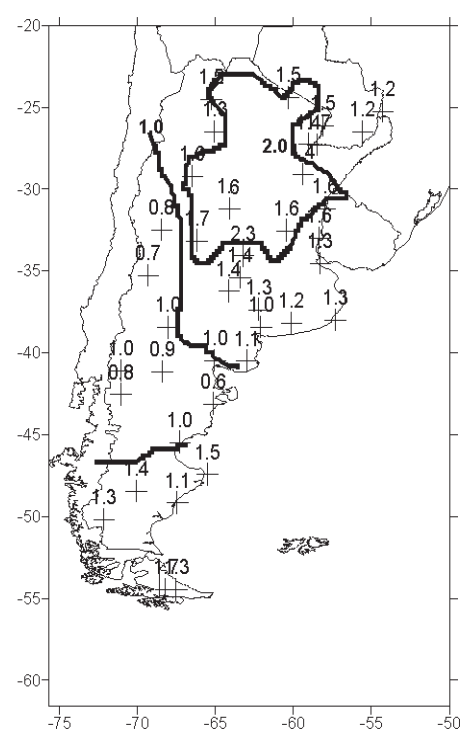

g)

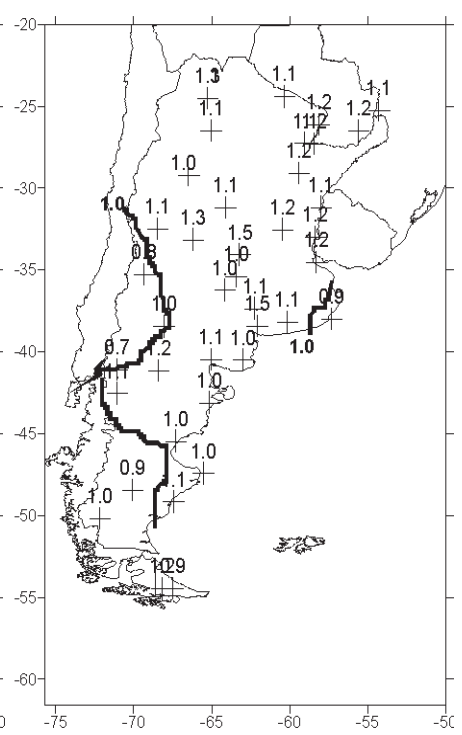

h)

Figure 10 - Mean geopotential height fields at $1000 \mathrm{hPa}(\mathrm{a}$ and b) and their anomalies (c and d) during persistent episodes (a and c) and the rest of the $I^{3} \mathrm{Im}-\sigma$ series (b and d) at I40. Mean temperature anomalies during persistent episodes (e) and the rest (f). $\mathrm{r}$ rainfalls during persistent episodes (g) and the remaining days $(\mathrm{h})$. 
This can also be seen in the anomaly field, where the negative anomaly located in the south of the country is more intense and displaced to the west. Negative anomalies are observed in summer and positive ones in winter, as cold air advection in summer is from the SW and in winter from the west.

When the index is calculated at $40^{\circ} \mathrm{W}$. (Figs. 8 and 9, e and $\mathrm{f}$ ).

To the north of $40^{\circ} \mathrm{S}$ :

Values of $r$ are greater than one in almost the whole region during both seasons. They are higher in the center east of the country in winter due to the intensification of a trough in the north and its greater expansion to the south. In summer, the Pacific anticyclone limits the trough (Figs. 5 and 6, e and f). There is a rainfall deficit in NW Argentina, which results from the more intense depression in the NW.

It rains more than at $\mathrm{I} 70$ over Patagonia in summer, as the flow from the west is less intense than at I40, which can be seen in the $1000 \mathrm{hPa}$ anomaly field with a flow from the south.

To the south of $40^{\circ} \mathrm{S}$.

It does not rain in winter in western Patagonia and the temperature anomalies are positive, due to a ridge at $1000 \mathrm{hPa}$ which can also be seen through the positive anomaly in southern Argentina and which penetrates deeper into the continent in winter than in summer.

A stronger cold air advection in summer produced by the SW flow causes negative temperature anomalies in summer.

\subsubsection{Persistent situations}

Mean temperature anomaly fields and rainfall relation fields were calculated on days with $\mathrm{I}<\mathrm{Im}-\sigma$ which compose the more persistent periods. The same was done for the rest of the series excluding the last mentioned episodes.

Both variables in the two samples had similar distributions in most of Argentina when the circulation was calculated at 100 and $70^{\circ} \mathrm{W}$ (not shown). On the other hand, for I40, the differences in temperature anomalies are significant in Patagonia. While mean anomalies corresponding to non-persistent episodes have negative values, anomalies for persistent episodes are positive.

Fig.10 shows the mean geopotential height fields and their anomalies at $1000 \mathrm{hPa}$ for persistent (a and c) and for nonpersistent situations ( $b$ and $c$ ), for I40. The same figure shows the mean temperature anomalies (e and f), the rainfall relation for both groups ( $\mathrm{g}$ and $\mathrm{h}$ ), a shift of the Pacific anticyclone to the south and a greater ridge intensity compared to the other days in the $\mathrm{I}<\mathrm{Im}-\sigma$ series according to the anomaly values (Fig.10 c). The subsidence produced by this intense system cause temperature to rise in Patagonia (Fig. 10 e).

The influence of the above positive anomaly on the reduction of rainfall in most of Patagonia is shown in Fig. 10 g. However, to the south the more meridional flow from the south produces greater humidity raising the values to more than one.

On the other hand, the northeasterly flow in the NE of the country enters the continent at higher latitudes during the persistent episodes and the negative anomaly associated to it together with the one over the Atlantic become more intense, causing warmer temperatures at some stations in the center of the country and more rain days in a large area of northern and central Argentina (Fig. 10 g).

\section{CONCLUSIONS}

The days with strong westerly circulation in which the zonal index $\mathrm{I}<\mathrm{Im}-\sigma$ for the period 89-98, applied at 100,70 and $40^{\circ} \mathrm{W}$, are more frequent in summer and spring and fewer in winter. The greatest frequency of sequences meeting these conditions is 1 or 2 days in length. The percentage of these cases preceded by one or two days with negative indices $(\mathrm{I}<0)$ correspond to 69,72 and $79 \%$ at 100,70 and $40^{\circ} \mathrm{W}$ respectively.

The mean geopotential height fields at 500 and $1000 \mathrm{hPa}$ show a strong gradient to the south of $40^{\circ} \mathrm{S}$ and cyclonic centers located to the south of $60^{\circ} \mathrm{S}$ at the longitudes studied. Mean geopotential height anomalies corresponding to the depressions mentioned are located around $55^{\circ} \mathrm{S}$.

Subtropical anticyclones at $500 \mathrm{hPa}$ are more intense at the three studied longitudes, which makes them more stable with the corresponding incidence on the $1000 \mathrm{hPa}$ level.

During intense westerly circulation episodes, temperature anomalies and the number of rain days in Argentina depend on the longitude considered.

Mean temperature anomalies are largely positive at the three longitudes analyzed. Exceptions are the negative anomalies in the north, extreme south and south of $40^{\circ} \mathrm{S}$ when I is estimated at 100,70 and $40^{\circ}$ respectively. In general, temperature anomalies are more positive in winter than in summer with the exception of the north for I at 100 and $70^{\circ}$ $\mathrm{W}$. The summer anomaly field at $40^{\circ} \mathrm{W}$ is very similar to the annual one.

As for precipitation, at any of the three longitudes selected, there are more rain days in southern Patagonia. In addition, at $100^{\circ} \mathrm{W}$, rainfall frequency increases in the WNW of Argentina. At $40^{\circ} \mathrm{W}$ high frequencies are found all over the country, except in the west to the north of $40^{\circ} \mathrm{S}$.

The summer $\mathrm{r}$ fields at $100^{\circ}$ and $40^{\circ} \mathrm{W}$ are similar to that of the whole period. At $70^{\circ} \mathrm{W}$ both seasons present similar 
characteristics to the annual ones, with a slight increase of $r$ in summer in part of the south and SW of the province of Buenos Aires. At $100^{\circ} \mathrm{W}$ the winter field presents values of $\mathrm{r}>1$ to the north of $40^{\circ} \mathrm{S}$, with the exception of the west. At $40^{\circ} \mathrm{W}$, winters are drier in the north of the country and the west of Patagonia.

The influence of persistent westerly circulation cases on temperature and precipitation is not different from the rest of the cases for I at 100 and $70^{\circ} \mathrm{W}$. At $40^{\circ} \mathrm{W}$ warmer temperatures are observed in Patagonia.

The simple application of index I made it possible to determine the days with the greatest westerly circulation intensity close to $45^{\circ} \mathrm{S}$ and its influence on temperature and rainfall in the whole country. The upward and downward trend of both variables may be diagnosed with more than $67 \%$ probability when 1 or 2 previous days with $\mathrm{I}<0$ have occurred.

\section{ACKNOWLEDGEMENTS}

The author is grateful to Dr. Erich Lichtenstein for his important and invaluable suggestions for this paper and the University of Buenos Aires for funding it (subsidy X234).

\section{REFERENCES}

ALESSANDRO, A. P. A Meridional Circulation index and the precipitation in Argentina. Australian Meteorology Magazine, v. 47, p.197-170, 1998.

ALESSANDRO A. P. Long waves around southamerica and precipitation in Argentina. Meteorological Applications, v. 8, n. 1, p. 85-95, 2001.

ALESSANDRO A. P.; DE GARÍN A. A study on predictability of human discomfort in Buenos Aires city. Meteorological Applications, v. 10, p. 263-271, 2003 a.

ALESSANDRO A. P. Blocking action situations in the south of South America during the 1990s. Meteorologica, v. 18, p. 23-37, 2003 b.

ALESSANDRO A. P. Influence of blocking on temperature and precipitation in Argentina during the 90's decade. Meteorologica, v. 18, p. 39-52, 2003 c.
ALESSANDRO A. P. Bloqueos simultáneos en el Atlántico y Pacífico sur y sus influencias sobre la República Argentina. Revista Brasileira de Meteorología, v. 20, n. 2, p. 277-300, 2005. a.

ALESSANDRO A. P. Synoptic features associated with critical water level rises in the Rio de la Plata. Meteorogical Application, v. 12, p. 123-133, 2005 b.

ALESSANDRO A. P. Acciones bloqueantes alrededor de los setenta grados oeste en el sur de sud América. Meteorológica, v. 30 , n. 1 y 2 , p. $3-25,2005$. c.

BERBERY E. H.; NUÑEZ M. N. An observational and numerical study of blocking episodes near South America. Journal of Climate, v. 2, p. 1352-1361, 1989

FERREIRA R. N. et al. Zonal Index Influences in South America, 27TH climate Diagnostics and Prediction Workshop, Virginia. p. 21-25, 2002.

JONES P. D.; SALINGER M. J. ; MULLAN A. B. Extratropical circulation indices in the southern Hemisphere based on station data. International Journal of Climatology, v. 19, p. 1301-1317, 1999.

KIDSON J. W. Index Cycles in the Southern Hemisphere during the Global Weather Experiment. Monthly Weather Review, v. 114, p.1654-1663, 1986.

LICHTENSTEIN E. R.. La depresión del noroeste argentino. Tesis doctoral. Universidad de Buenos Aires, 1980.

NAMÍAS J. ; CLAPP P. F. Observational studies of general circulation patterns. Compendium of Meteorology. The American Meteorological Society, p. 551-568, 1951.

PROHASKA F. J. Regímenes estacionales de la precipitación de Sudamérica y mares vecinos desde $15^{\circ} \mathrm{S}$ hasta Antártida. Meteoros, Año II, n. 1 y 2, p. 66-100, 1952.

SCHWERDTFEGER W. Bases para el pronóstico a medio plazo de las condiciones de temperatura para el otoño en Buenos Aires. Meteoros, Año I. n. 1, p. 33-45, 1951.

VELASCO I ;. NECCO G. V. Valores medios, extremos y desviaciones standard de datos aerológicos de la República Argentina. Universidad de Buenos Aires -Facultad de Ciencias Exactas y Naturales. Dto. de Meteorología, 1980 . 